\title{
URGENSI PENGAWASAN ORGANISASI KEMASYARAKATAN OLEH PEMERINTAH
}

\section{URGENCY OF COMMUNITY SUPERVISION ORGANIZATION BY GOVERNMENT}

\author{
Catur Wibowo dan Herman Harefa \\ Badan Penelitian dan Pengembangan (BPP) Kementrian Dalam Negeri \\ J1. Kramat Raya No. 132 - Senen, Jakarta \\ No. Telp./Faks : +62 213140454 ; HP. +62 81315345149 \\ Email : caturbpp@gmail.com
}

Dikirim: 3 Februari 2015 Direvisi: 31 Agustus 2015 Disetujui:15 Februari 2015

\begin{abstract}
Abstrak
Kajian Urgensi Pengawasan Organisasi Kemasyarakatan bertujuan untuk mendeskripsikan gambaran realitas permasalahan Ormas di daerah; mendeskripsikan implementasi peran pemerintah (termasuk pemerintah daerah) dalam melakukan pengawasan terhadap Ormas; dan memberikan rekomendasi mengenai hal-hal yang perlu diatur dalam rancangan peraturan pemerintah tentang pengawasan ormas. Kajian ini menggunakan pendekatan kualitatif, dengan tujuan agar dapat diperoleh informasi yang mendalam dan lengkap tentang berbagai hal terkait dengan keberadaan ormas dan dinamikanya di daerah. Hasil studi dapat dikemukakan: bahwa di satu sisi keberadaan ormas memberikan kontribusi yang tidak kecil dalam pembangunan, namun di sisi lain masih banyaknya organisasi masyarakat yang bertindak anarkis dan menganggu dalam lingkungan masyarakat; untuk itu seluruh ketentuan operasional dalam rangka implementasi UU Ormas harus sudah tersedia; hal-hal substansial yang perlu diatur dalam pengawasan ormas oleh Pemerintah.

Kata kunci : Urgensi Pengawasan Organisasi Kemasyarakatan, oleh Pemerintah.
\end{abstract}

\begin{abstract}
Urgency Surveillance Study of Social Organizationaims to describe the reality of the problems in the a real of Social Organization; describe the implementation of the role of government (including local government) in controlling the Social Organization; and provider ecommendations on matters that need to beregulated in the draft regulations on the supervision of organizations. This studyused a qualitative approach, withthe aim that can be obtained in-depth and complete information about matters relating to the existence and dynamic sinregiona lorganizations. The study results presented can be: that on the one hand the existence of organizations that do not contribute little in development, buton the other hand there are many community organizations that act an archic and disturbing in society; for the entire operational provisions for the implementation of Social Organization must be available; things that need to be arranged substantially in the massur veillance by the government.

Keywords: SurveillanceUrgencyof Social Organization, bythe Government.
\end{abstract}

\section{PENDAHULUAN}

Salah satu hak yang dianggap sebagai salah satu yang hak fundamental bagi manusia adalah kebebasan untuk berserikat atau berorganisasi (freedom of association),kebebasan berkumpul (freedom of assembly), dan kebebasan menyatakan pendapat (freedom of expression). Hak ini dikenal sebagai tiga kebebasan dasar yang merupakan bagian dari konsep hak-hak asasi manusia, terutama dalam rumpun hak sipil dan politik. Dasar hukum kebebasan untuk berserikat dan berkumpul serta mengeluarkan pendapat yang berlaku secara universal adalah Pasal 20 Deklarasi Umum Hak Asasi Manusia (DUHAM); Pasal 21 Kovenan Hakhak Sipil dan Politik; Pasal 5 huruf d angka viii Konvensi Penghapusan Diskriminasi Rasial, dan yang terbaru Resolusi No15/21 tahun tentang "The rights to freedom of peaceful assembly and of association" yang diterima Dewan HAM PBB pada 6 Oktober 2010 (Elsam,2013).

Secara nasional perlindungan terhadap hakhak terkait dengan kebebasan berserikat, berkumpul, dan mengeluarkan pendapat diatur dalam UUD 1945 dan UU No. 39 tahun 1999 tentang HAM. UndangUndang Dasar 1945 telah menjamin tiap orang berhak atas kebebasan berserikat, berkumpul dan berpendapat sebagaimana diatur dalam pasal $28 \mathrm{E}$ ayat (3) yang menyatakan bahwa "setiap orang berhak atas kebebasan berserikat, berkumpul, dan mengeluarkan pendapat". Ketentuan UUD 1945 tersebut kemudian ditegaskan kembali di dalam Pasal 24 UU No. 39 tahun 1999 tentang Hak Asasi Manusia, yang menyatakan bahwa "setiap orang berhak untuk berkumpul, berapat, dan berserikat untuk maksud-maksud damai. Setiap warga negara atau kelompok masyarakat berhak mendirikan partai politik, lembaga swadaya masyarakat atau organisasi 
lainnya untuk berperan serta dalam jalannya pemerintahan dan penyelenggaraan negara sejalan dengan tuntutan perlindungan, penegakan, dan pemajuan hak asasi manusia dengan ketentuan peraturan perundang-undangan".

Salah satu bentuk dari implementasi atas hak setiap orang berhak untuk berkumpul, berapat, dan berserikat tersebut adalah pembentukan organisasi kemasyarakatan (Ormas) sebagai salah satu wadah bagi masyarakat untuk mengaktualisasikan kebebasannya dalam berserikat dan berkumpul. Ormas merupakan salah satu wujud dari partisipasi masyarakat dalam mengembangkan demokrasi dalam upaya menjunjung tinggi kebebasan, kesetaraan, kebersamaan, dan kejujuran. Ormas merupakan organisasi yang dibentuk oleh sekelompok warga negara Republik Indonesia secara sukarela atas dasar persamaan kehendak dan cita-cita untuk memperjuangkan kepentingan anggota, masyarakat, bangsa, dan negara (Elsam, 2013)

Dalam penjelasan UU No 17 Tahun 2013 Tentang Organisasi Kemasyarakatan Ormas dengan segala bentuknya hadir, tumbuh dan berkembang sejalan dengan sejarah perkembangan kehidupan bermasyarakat, berbangsa dan bernegara. Dalam sejarah perjuangan kemerdekaan negara Republik Indonesia, Ormas merupakan wadah utama dalam pergerakan kemerdekaan, diantaranya Boedi Oetomo, Muhammadiyah, Nahdlatul Ulama, dan Ormas lain yang didirikan sebelum kemerdekaan Republik Indonesia. Peran dan rekam jejak Ormas yang telah berjuang secara ikhlas dan sukarela tersebut mengandung nilai sejarah dan merupakan aset bangsa yang sangat penting bagi perjalanan bangsa dan negara.

Dinamika perkembangan Ormas dan perubahan sistem pemerintahan membawa paradigma baru dalam tata kelola organisasi kemasyarakatan dalam kehidupan bermasyarakat, berbangsa, dan bernegara. Pertumbuhan jumlah Ormas, sebaran dan jenis kegiatan Ormas dalam kehidupan demokrasi makin menuntut peran, fungsi dan tanggung jawab Ormas untuk berpartisipasi dalam upaya mewujudkan cita-cita nasional bangsa Indonesia, serta menjaga dan memelihara keutuhan dan kedaulatan Negara Kesatuan Republik Indonesia. Peningkatan peran dan fungsi Ormas dalam pembangunan memberi konsekuensi pentingnya membangun sistem pengelolaan Ormas yang memenuhi kaidah Ormas yang sehat sebagai organisasi nirlaba yang demokratis, profesional, mandiri, transparan, dan akuntabel. Oleh karena itu, dinamika Ormas dengan segala kompleksitasnya menuntut pengelolaan dan pengaturan hukum yang lebih komprehensif melalui undang-undang.

Untuk mengakomodasi dinamika dan perkembangan Ormas tersebut pemerintah telah mengeluarkan UU No. 17 Tahun 2013 tentang Organisasi Kemasyarakatan yang menggantikan UU No. 8 Tahun 1985 tentang Organisasi
Kemasyarakatan yang dirasakan sudah kurang sesuai dengan perkembangan. Pasal 1 ayat (1) UU No. 17 Tahun 2013 dinyatakan bahwa yang dimaksud dengan organisasi kemasyarakatan adalah organisasi yang didirikan dan dibentuk oleh masyarakat secara sukarela berdasarkan kesamaan aspirasi, kehendak, kebutuhan, kepentingan, kegiatan, dan tujuan untuk berpartisipasi dalam pembangunan demi tercapainya tujuan Negara Kesatuan Republik Indonesia yang berdasarkan Pancasila.Mengacu pada definisi tersebut, maka segala macam organisasi bisa masuk ke dalam pengertian ormas, baikorganisasi yang bersifat sosial maupun non profit. Selain itu, berbagai bentuk organisasiseperti asosiasi atau perkumpulan keilmuan/profesi/hobi baik beriuran maupuntidak, pengajian, paguyuban keluarga, yayasan yang mengelola lembaga pendidikandan rumah sakit, panti asuhan, dan berbagai organisasi lainnya berada pada kategori ormas sesuai dengan yang diaturdalam pengertian tersebut.

Dengan demikian maka definisi ormassangat luas cakupannya. Dalam hal ini kemudian pemerintah memiliki wewenang untukmenentukan ormas tersebut bisa diterima atau tidak, karena tiap ormas mempunyaikewajiban mendaftarkan diri pada pemerintah dengan berbagai persyaratan.Pemerintah akan menseleksi apakah ormas tersebut boleh melakukan aktivitas atau tidak. Di Indonesia saat ini ada sekitar 139.957 ormas yang terdaftar, dengan rincian 65.577 ormas tercatat di Kemendagri, 25.406 tercatat di Kemensos dan 48.886 tercatat di Kemenkumham. Data tersebut belum ditambah ormas yang terdaftar di kementerian Kemenlu, Kemenhut dan lainnya (Kalyanamitra, 2013)

Banyaknya jumlah, jenis, bentuk, aktivitas, maupun tujuan Ormas membuat dinamika keormasan sangat tinggi. Pada satu sisi hak-hak dan kebebasan setiap warga negara harus dipenuhi, namun pada sisi lain hak-hak untuk mendapatkan perlindungan keamanan dan ketertiban umum juga harus tetap dapat ditunaikan. Perbedaan-perbedaan antar ormas bisa memunculkan berbagai masalah yang dapat mengganggu ketentraman dan ketertiban masyarakat. Dalam aktivitasnya sehari-hari harus diakui bahwa organisasi masyarakat tidak luput dengan hal-hal negatif yang merugikan masyarakat dan merusak citra organisasi masyarakat itu sendiri. Misalnya muncul organisasi masyarakat dengan motivasi mencari keuntungan ekonomi dan politik atau yang menggunakan cara-cara kekerasan untuk mencapai tujuannya.

Aksi-aksi kekerasan yang dilakukan ormas sering terjadi dan dikhawatirkan akan memecah belah persatuan yang telah terjalin di Indonesia. Sementara itu Kemendagri yang bertugas untuk mengawasi keberadaan ormas-ormas menghadapi kesulitan untuk mengawasi dan melakukan pembinaan,terlebih masih banyak ormas yang belum terdaftar resmi di Kemendagri, sehingga Kemendagri kesulitan untuk memberikan sanksi terhadap ormas- 
ormas yang melanggar ketentraman dan keamanan tanpa adanya aturan pelaksanaan dari UU No. 17 Tahun 2013. Oleh karena itu, sejalan dengan telah dikeluarkannya UU No. 17 Tahun 2013 tentang Organisasi Kemasyarakatan diperlukan adanya kajian mengenai pentingnya pengawasan Ormas sebagai bentuk implementasi pasal 53 UU No. 17 Tahun 2013.

Organisasi kemasyarakatan merupakan perwujudan dari hak yang dijamin dalam UndangUndang Dasar Negara Republik Indonesia Tahun 1945. Warga negara memiliki kebebasan untuk berserikat, berkumpul, dan mengeluarkan pendapat. Kebebasan untuk berserikat dan berkumpul serta mengeluarkan pendapat tersebut dikenal sebagai tiga kebebasan dasar yang merupakan bagian dari konsep hak-hak asasi manusia, terutama dalam rumpun hak sipil dan politik.

Organisasi kemasyarakatan menjadi sarana untuk menyalurkan pendapat dan pikiran bagi anggota masyarakat Warganegara Republik Indonesia dan dinilai memiliki peranan yang sangat penting dalam meningkatkan keikutsertaan secara aktif seluruh lapisan masyarakat dalam mewujudkan masyarakat Pancasila berdasarkan Undang-Undang Dasar 1945 dalam rangka menjamin pemantapan persatuan dan kesatuan bangsa, menjamin keberhasilan pembangunan nasional sebagai pengamalan Pancasila, dan sekaligus menjamin tercapainya tujuan nasional.

Organisasi masyarakat sering pula dikenal dengan istilah lembaga swadaya masyarakat (disingkat LSM),yakni sebuah organisasi yang didirikan oleh perorangan ataupun sekelompok orang yang secara sukarela yang memberikan pelayanan kepada masyarakat umum tanpa bertujuan untuk memperoleh keuntungan dari kegiatannya.Organisasi ini dalam terjemahan harfiahnya dari Bahasa Inggris dikenal juga sebagai Organisasi non pemerintah (disingkat ornop atau ONP (Bahasa Inggris: nongovernmental organization; $N G O)$.

Organisasi tersebut bukan menjadi bagian dari pemerintah, birokrasi ataupun negara. Maka secara garis besar organisasi non pemerintah dapat di lihat dengan ciri sebagai berikut: a) Organisasi ini bukan bagian dari pemerintah, birokrasi ataupun negara; b) Dalam melakukan kegiatan tidak bertujuan untuk memperoleh keuntungan (nirlaba); c) Kegiatan dilakukan untuk kepentingan masyarakat umum, tidak hanya untuk kepentingan para anggota seperti yang di lakukan koperasi ataupun organisasi profesi.

Secara garis besar dari sekian banyak organisasi non pemerintah yang ada dapat di kategorikan sebagai berikut: a) Organisasi donor, adalah organisasi non pemerintah yang memberikan dukungan biaya bagi kegiatan ornop lain; b) Organisasi mitra pemerintah, adalah organisasi non pemerintah yang melakukan kegiatan dengan bermitra dengan pemerintah dalam menjalankan kegiatanya; c) Organisasi profesional, adalah organisasi non pemerintah yang melakukan kegiatan berdasarkan kemampuan profesional tertentu seperti ornop pendidikan, ornop bantuan hukum, ornop jurnalisme, ornop kesehatan, ornop pengembangan ekonomi dll; d) Organisasi oposisi, adalah organisasi non pemerintah yang melakukan kegiatan dengan memilih untuk menjadi penyeimbang dari kebijakan pemerintah. Ornop ini bertindak melakukan kritik dan pengawasan terhadap keberlangsungan kegiatan pemerintah.

Sebuah laporan PBB tahun 1995 mengenai pemerintahan global memperkirakan ada sekitar 29.000 ONP internasional. Jumlah di tingkat nasional jauh lebih tinggi: Amerika Serikat memiliki kira-kira 2 juta ONP, kebanyakan dibentuk dalam 30 tahun terakhir. Russia memiliki 65.000 ONP. Lusinan dibentuk per harinya. Di Kenya, sekitar 240 NGO dibentuk setiap tahunnya.

Menurut Jimly Asshiddiqie, dalam kehidupan berbangsa, dapat dibedakan adanya jenis-jenis organisasi yang bekerja dalam tiga ranah kehidupan bersama, yaitu dalam ranah negara (state), masyarakat (civil society), dan dunia usaha (market). Pembedaan dan bahkan pemisahan ketiganya haruslah dijadikan perspektif baru dalam membangun pengertian-pengertian mengenai organisasi modern, termasuk mengenai organisasi kemasyarakatan sejalan dengan perkembangan ide mengenai prinsip "legal and constitutional government" dan gagasan "good governance". Bahkan dewasa ini berkembang pula pandangan yang semakin kuat bahwa komunitas organisasi di ketiga ranah negara, masyarakat, dan dunia usaha itu haruslah berada dalam posisi yang seimbang dan saling menunjang satu sama lain untuk menopang dinamika kemajuan bangsa.

Oleh sebab itu, dalam menyiapkan pengaturan-pengaturan oleh negara terhadap aneka bentuk dan jenis organisasi tersebut, perlu diperhatikan pentingnya (i) prinsip pemisahan (decoupling) antar ranah negara, masyarakat, dan dunia usaha itu, (ii) prinsip "legal and onstitutional organization", (iii) prinsip "good governance", dan (iv) kebutuhan akan "organizational empowerment" dalam rangka (v) perwujudan prinsip "freedom of association" yang (vi) tetap menjamin, mencerminkan, dan tidak mengurangi arti dari prinsip-prinsip kebebasan berkeyakinan, kebebasan berpikir, dan kebebasan berpendapat (freedom of belief, freedom of thought, and freedom of expression).

Di masing-masing ranah, terdapat beraneka macam dan jenis organisasi yang dibentuk oleh pendirinya dengan maksud untuk mencapai tujuan bersama. Organisasi dalam ranah struktur negara tersusun atas dasar jabatan-jabatan secara horizontral, vertical dan bahkan diagonal, sehingga oleh Logemann organisasi negara itu disebut sebagai organisasi jabatan (ambten organisatie). Secara umum, organisasi jabatan dibedakan dalam cabang- 
cabang:1)Cabang eksekutif; 2)Cabang legislative; 3)Cabang judisial;4)Cabang-cabang campuran atau cabang lainnya.

Sementara itu, organisasi dalam ranah dunia usaha dapat dibedakan antara persekutuan orang dan persekutuan kekayaan kapital. Organisasi yang dapat dikategorikan sebagai persekutuan orang adalah Koperasi, sedangkan organisasi yang merupakan perkumpulan modal atau capital adalah perseroan terbatas yang tersusun atas nilai saham. Organisasi negara juga ada yang bersifat persekutuan kekayaan yang dipisahkan dari kekayaan negara, yaitu Badan Hukum Milik Negara (BHMN) dan Badan Usaha Milik Negara (BUMN).

Sehubungan dengan itu, organisasi dalam lingkungan kemasyarakatan juga dapat dibedakan antara persekutuan orang dan persekutuan kekayaan itu. Bahkan, organisasi kemasyarakatan ada pula yang merupakan pesekutuan organisasi atau institusi, seperti badan kerjasama perguruan tinggi, dan sebagainya. Yang termasuk organisasi kemasyarakatan dengan kategori persekutuan kekayaan adalah:a)Yayasan yang diatur berdasarkan UU No. 28 Tahun 2004 tentang Yayasan; danb)Badan wakaf yang diatur berdasarkan UU tentang Wakaf.

Sedangkan organisasi kemasyarakatan atau organisasi masyarakat dengan kategori persekutuan organisasi dapat terdiri atas organisasi-organisasi berbadan hukum atau organisasi bukan berbadan hukum. Di samping itu, ada pula kemungkinan organisasi yang menjadi anggota itu, tidak termasuk kategori organisasi kemasyarakatan. Misalnya, Asosiasi Pemerintahan Daerah, Asosiasi DPRD, Asosiasi Gubernur, Asosiasi Walikota, dan sebagainya. Apakah asosiasi-asosiasi semacam ini dapat dikategorikan sebagai organisasi kemasyarakatan atau bukankah? Jika asosiasiasosiasi ini didaftarkan untuk mendapatkan status badan hukum, dapatkah diterima dan diberikan status badan hukum? Menurut saya, yang seharusnya diterima untuk membentuk organisasi bukanlah organisasi negaranya seperti Gubernur, Walikopta, dan DPRD, tetapi orang per orang yang menduduki jabatan-jabatan Gubernur, Bupati, Walikota, atau Anggota DPRD yang bersangkutan. Jadi yang berorganisasi bukanlah lembaganya melainkan orangnya. Kalau demikian maka nama organisasi Asosiasi Pemerintahan Daerah, Asosiasi Gubernur, dan sebagainya itu harus dipersoalkan, apalagi jika kegiatan organisasi itu menggunakan anggaran belanja daerah.

Sementara itu, organisasi kemasyarakatan yang termasuk kategori persekutuan orang adalah:a)Partai Politik yang diatur dengan UU tentang Partai Politik;b)Perkumpulan (Vereeniging) berbadan hukum yang diatur berdasarkan Staatsblad 1870 No. 64;c)Lembaga Swadaya Masyarakat yang diatur berdasarkan UU Lingkungan Hidup Tahun
1982; dand)Organisasi Kemasyarakatan yang diatur berdasarkan UU No. 8 Tahun 1985.

Di samping itu, diberbagai bidang kegiatan partisipasi masyarakat yang terkait dengan kegiatan instansi-instansi pemerintahan, terdapat pula berbagai macam organisasi yang diatur tersendiri instansi yang bersangkutan. Misalnya, organisasi masyarakat penyelenggara dakwah keagamaan, pendidikan, kesehatan, sosial, lingkungan hidup, dan sebagainya. Kesemua jenis organisasi dimaksud dirangkumkan pengaturannya oleh UU No. 8 Tahun 1985 yang bersifat mencakup. Semua jenis dan macam-macam organisasi tersebut, perlu dibuat kategorisasi dan klasifikasi agar dapat dipahami dengan jenis faktor-faktor pembedanya satu dengan yang lain.

Untuk itu, kategorisasi dimaksud dapat dibedakan antara (1) status badan hukum dan bukan badan hukumnya dan (2) kategorinya sebagai persekutuan orang atau persekutuan kekayaan. Di samping itu, kategorisasi dapat pula dilihat dari (3) susunan organisasinya yang bersifat massal atau merupakan sistem unit. Jika keanggotaan bersifat massal, maka organisasi itu biasanya disebut sebagai organisasi massa dengan susunan yang terdiri atas cabang-cabang dan ranting, seperti Nahdhatul Ulama dan Muhammadiyah. Sedangkan keanggotaan organisasi unit tidak bersifat massal, melainkan terbatas, sehingga struktur organisasinya hanya sebagai 1 unit organisasi, tidak memiliki cabang di daerah-daerah, melainkan hanya kantor perwakilan saja. Selain itu, organisasi kemasyarakatan dapat pula dibedakan dari (4) lingkup kegiatannya yang bersifat umum atau bersifat khusus menurut bidangbidang tertentu saja, misalnya hanya di bidang pendidikan, atau kesehatan saja. Dalam praktik, ada organisasi dengan keangotaan yang bersifat massal dan dengan kegiatan yang bersifat umum, mencakup semua bidang yang sangat luas, seperti organisasi Nahdhatul Ulama dan Muhammadiyah tersebut di atas.

Sebaiknya perbedaan-perbedaan tersebut diatur secara berbeda-beda satu dengan yang lain atau setidaknya beberapa di antaranya diatur berbeda. Demikian pula untuk memudahkan pemahaman, penamaan pelbagai jenis organisasi itu juga dapat dibedakan. Misalnya, selama ini pengertian ormas lebih dikenal sebagai organisasi massa, sampai ditetapkannya UU No. 8 Tahun 1985 yang mengatur tentang Organisasi Kemasyarakatan yang biasa disingkat juga sebagai ormas. Padahal ada perbedaan prinsipil antara pengertian organisasi kemasyarakatan dengan organisasi masyarakat, dan apalagi dengan organisasi massa. Kata kemasyarakatan menunjuk kepada pengertian sifat kemasyarakatan atau sifat kegiatan kemasyarakatan, sedangkan masyarakat pada organisasi masyarakat menunjuk kepada pengertian organisasi non-negara atau non-pemerintah, atau organisasi milik masyarakat. Demikian pula yang dimaksud dengan 
organisasi massa, adalah organisasi masyarakat dengan keanggotaan yang bersifat massal.

Organisasi yang mencerminkan atau pelembagaan prinsip kemerdekaan berserikat dapat terbentuk sebagai badan hukum (rechtspersoon). Namun, tidak semua organisasi memerlukan status badan hukum. Jika organisasi tersebut tidak menyangkut kepentingan umum atau berkenaan urusan masyarakat luas, sangat mungkin organisasi itu tidak memerlukan status yang ketat sebagai badan hukum (rechtspersoon). Namun, organisasi yang tidak berbadan hukum ini ada juga yang kegiatannya berkaitan dengan kepentingan umum atau berhubungan dengan program-program pemerintah sehingga memerlukan pengaturan dengan undangundang.

Organisasi yang berstatus badan hukum tentu berbeda dari organisasi yang bukan badan hukum. Dengan status badan hukum itu, organisasi yang bersangkutan dapat bertindak sebagai subjek yang otonom atau penuh dalam lalu lintas hukum. Badan hukum organisasi menyandang hak dan kewajiban dalam lalu lintas hukum. Misalnya, organisasi badan hukum dapat diberi hak-hak (i) untuk memiliki rekening bank atas nama organisasi, (ii) untuk memiliki saham atau surat-surat berharga lainnya atas nama organisasi, (iii) untuk memiliki harta bergerak dan tidak bergerak, khususnya (iv) hak atas tanah atas nama organisasi. Organisasi yang tidak berbadan hukum tidak dapat memiliki semua hakhak yang dapat diberikan kepada organisasi berbadan hukum tersebut.

Status badan hukum itu sendiri harus ditetapkan secara resmi melalui pendaftaran di instansi pemerintah. Terkait hal itu, perlu dibedakan antara (i) registrasi status badan hukum dan (ii) registrasi atau izin operasional kegiatan, dan (iii) standarisasi dan akreditasi dalam rangka pembinaan mutu. Registrasi badan hukum harus tersentralisasi dalam sistem administrasi hukum Kementerian Hukum dan HAM. Sedangkan registrasi atau izin operasional kegiatan dapat ditentukan dikaitkan dengan kementerian yang bertanggungjawab dalam bidang kegiatan yang bersangkutan. Misalnya, kegiatan organisasi di bidang pendidikan harus terdaftar di atau memiliki izin operasional dari Kementerian Pendidikan dan Kebudayaan, organisasi keagamaan harus terdaftar di atau mendapatkan izin operasional dari Kementerian Agama, organisasi social harus terdaftar di atau diberi izin operasional dari Kementerian Sosial, dan sebagainya. Oleh karena itu, tidak perlu diadakan pengaturan yang menentukan harus adanya pendaftaran di Kementerian Dalam Negeri, kecuali untuk organisasi asing yang beroperasi di Indonesia dan organisasi warga negara asing yang ada di Indonesia yang harus diawasi oleh kementerian yang bertanggungjawab untuk urusan pengawasan orang asing.

Di samping itu, dapat dipersoalkan, setelah organisasi tersebut mendapatkan status badan hukum, apakah kepadanya masih harus dikenakan ketentuan untuk mendapatkan izin operasional untuk melakukan sesuatu kegiatan? Ketentuan mengenai perizinan didasarkan atas premis bahwa kegiatan yang bersangkutan pada dasarnya dilarang, kecuali apabila telah mendapatkan izin untuk dilakukan. Padahal, (i) pada dasarnya setiap orang berhak untuk bebas berorganisasi atau berserikat, dan (ii) organisasinya itu sendiri, apalagi misalnya, telah didaftarkan secara resmi dan mendapatkan status badan hukum sebagaimana mestinya, juga harus dipandang memiliki kebebasan untuk mengadakan kegiatan yang tidak melanggar hukum. Untuk apa lagi organisasi itu diharuskan mendapatkan izin operasional? Bukankah baginya cukup ditentukan harus mendaftarkan diri pada instansi pemerintah yang membina bidang kegiatan yang bersangkutan, sehingga organisasi yang bersangkutan dapat mengikuti pelbagai ketentuan yang berlaku di lingkungan instansi yang bersangkutan, termasuk untuk kepentingan standarisasi dan akreditasi. Jika organisasi yang bersangkutan ternyata melakukan pelanggaran, bukan kah atas dasar itu, statusnya sebagai badan hukum dapat dipersoalkan sebagaimana mestinya? Karena sebenarnya, kepada semua organisasi berbadan hukum seharusnya dapat ditentukan cukup memastikan (i) terdaftar sebagai badan hukum, (ii) terdaftar sebagai penyelenggara kegiatan tertentu di lingkungan kementerian negara yang bersangkutan, dan (iii) diakreditasi oleh instansi pemerintah yang bersangkutan untuk kepentingan pembinaan mutu.

Misalnya, partai politik diharuskan oleh UU tentang Partai Politik untuk (i) mendapatkan status badan hukum dari Kementerian Hukum dan HAM, dan (ii) terdaftar sebagai peserta pemilihan umum di Komisi Pemilihan Umum. Untuk mendapatkan status sebagai badan hukum dan status sebagai peserta pemilu itu tidak mudah, melainkan harus memenuhi banyak persyaratan. Kalaupun sudah berstatus badan hukum, mungkin saja, partai politik yang bersangkutan tidak memenuhi persyaratan menjadi peserta pemilu, sehingga kegiatannya untuk mendudukkan wakilnya di parlemen menjadi terhalang. Demikian pula organisasi kemasyarakatan yang aktif di bidang pendidikan, misalnya, mungkin saja tidak terdaftar atau tidak lagi terdaftar sebagai penyelenggara pendidikan yang terakreditasi, sehingga kegiatannya seakan dibekukan, meskipun eksistensinya sebagai organisasi tetap diakui. Tetapi, apabila organisasi itu melakukan pelanggaran tertentu yang dapat dijadikan alasan untuk dibubarkan sebagaimana mestinya, maka organisasi tersebut dengan sendirinya dapat pula dibubarkan dengan pembatalan statusnya sebagai badan hukum.

Sesuai dengan UU No. 17 Tahun 2013 tentang Organisasi Kemasyarakatan, pengertian Ormas secara umum adalah organisasi yang didirikan dengan sukarela oleh warga negara Indonesia yang dibentuk berdasarkan kesamaan 
tujuan, kepentingan, dan kegiatan, untuk dapat berpartisipasi dalam pembangunan demi tercapainya tujuan Negara Kesatuan Republik Indonesia. Pengertian Ormas tersebut dimaksudkan untuk mewadahi semua organisasi atau lembaga yang dibentuk masyarakat yang dibentuk dengan tiga pilar dasar, yaitu kesamaan tujuan, kepentingan, dan kegiatan sebagai sarana untuk menyalurkan pendapat dan pikiran bagi anggota masyarakat Warganegara Republik Indonesia dan meningkatkan keikutsertaan secara aktif seluruh lapisan masyarakat dalam mewujudkan masyarakat Pancasila berdasarkan Undang-Undang Dasar 1945, dan sekaligus menjamin tercapainya tujuan nasional.

Dalam kerangka hak asasi manusia dan 'kebebasan berserikat, berkumpul, dan mengeluarkan pendapat, maka Ormas dapat berbadan hukum atau tidak berbadan hukum. Ormas yang berbadan hukum dapat memilih bentuk perkumpulan atau yayasan. Kedua bentuk Ormas tersebut berkaitan dengan pendirian, bahwa Ormas yang berbadan hukum Perkumpulan didirikan dengan persyaratan berbasis keanggotaan. Sementara, Ormas yang berbadan hukum yayasan didirikan dengan persyaratan tidak berbasis keanggotaan. Pada pendirian, maka persyaratan yang diberlakukan sesuai dan sinkron dengan pengaturan mengenai yayasan dan perkumpulan. Dalam Undang-Undang Nomor 16 Tahun 2001 tentang Yayasan, Pasal 9 diatur bahwa yayasan didirikan oleh satu orang atau lebih. Karena itu, pada prinsip umum, maka pendirian Ormas dapat dilakukan oleh satu orang atau lebih.

Mengenai persyaratan pendirian lebih lanjut, maka Ormas yang berbadan hukum yayasan sesuai dengan persyaratan dalam Undang-Undang Nomor 16 Tahun 2001 tentang Yayasan. Sementara, Ormas yang berbadan hukum perkumpulan dapat didirikan dengan persyaratan memiliki: akta pendirian; AD/ART; program kerja; sumber pendanaan; surat keterangan domisili; nomor pokok wajib pajak atas nama perkumpulan; pernyataan tidak berafiliasi kepada partai politik; pernyataan tidak sedang dalam sengketa kepengurusan atau dalam perkara di pengadilan; dan pengesahan sebagai badan hukum perkumpulan dari menteri yang tugas dan tanggung jawabnya di bidang hukum dan hak asasi manusia. Pengesahan sebagai badan hukum perkumpulan tersebut dilakukan setelah meminta pertimbangan dari instansi yang terkait. Salah satu pertimbanganya, instansi terkait lebih memiliki aparatur yang dapat memberikan pertimbangan terhadap ruang lingkup kegiatan ormas tersebut.

Dalam rangka mengoptimalkan peran dan fungsi Ormas, maka Ormas yang berbadan hukum perkumpulan atau yayasan diperbolehkan untuk menggabungkan diri dalam wadah bersama. Untuk tetap memberikan kebebasan dalam pembentukan Ormas, maka wadah bersama yang dibentuk tersebut tidak bersifat tunggal dan memonopoli keseluruhan lingkup kegiatan dan kerja Ormas. Dalam kerangka pemberitahuan kepada negara, maka Ormas berbadan hukum secara otomati terdaftar setelah memperoleh pengesahan mengenai badan hukum yang dimiliki. Sementara, pendaftaran Ormas yang tidak berbadan hukum dilakukan dengan pemberian surat keterangn terdaftar (SKT) oleh Pemerintah dan Pemerintah Daerah dengan persyaratan: akta pendirian; AD dan ART; program kerja; kepengurusan; surat keterangan domisili; nomor pokok wajib pajak atas nama Ormas; surat pernyataan tidak berafiliasi kepada partai politik; pernyataan tidak sedang dalam sengketa kepengurusan atau dalam perkara di pengadilan; dan surat pernyataan kesanggupan melaporkan kegiatan. Kelembagaan pemerintah yang berwenang memberikan SKT diatur sesuai dengan ruang lingkup kegiatan dan wilayah kerja Ormas berdasarkan pada ruang lingkup pemerintahan. SKT dapat diterbitkan oleh Menteri, gubernur, atau bupati/walikota sesuai kewenangan. Pengaturan ini dilakukan sesuai dengan ketentuan pendesentralisasian urusan pemerintahan dan otonomi daerah.

\section{METODE}

Kajian ini menggunakan pendekatan kualitatif, dengan tujuan agar dapat diperoleh informasi yang mendalam dan lengkap tentang berbagai hal terkait dengan keberadaan ormas dan dinamikanya di daerah.Untuk maksud tersebut, teknik pengumpulan data yang utama adalah studi kepustakaan (library study), yakni mengumpulkan data dari berbagai sumber tertulis yang tersedia, baik dari surat kabar cetak maupun elektronik, majalah, hasil penelitian, jurnal, dan sumber-sumber sekunder lainnya. Namun demikian, untuk mempertajam analisis digunakan pula metode pengumpulan data di lapangan (field study) melalui wawancara dengan beberapa informan. Informan yang dipilih adalah para perwakilan dari organisasi masyarakat, serta perwakilan pihak pemerintah daerah yang terlibat dalam pengambilan kebijakan dalam rangka pembinaan dan pengawasan ormas di daerahnya. Teknik untuk memetakan persoalan-persoalan ormas adalah pendekatan dari bawah ke atas (bottom-up approach). Melalui teknik ini, peneliti memulai memetakan persoalan pada level terbawah (street level bureaucrat)ditingkat masyarakat, tingkat pengambil kebijakan di level Kabupaten/Kota, kemudian naik pada level yang lebih tinggi yaitu para pembuat kebijakan secara berjenjang sampai pada level K/L terkait. Adapun bagan alur kajian mengenai Urgensi Pengawasan Ormas oleh Pemerintah dapat dilihat pada Gambar 1.

\section{HASIL DAN PEMBAHASAN}

\section{Gambaran Realitas Permasalahan Ormas Di Daerah}


Gambar 1. Bagan Alur Pikir Kajian : Urgensi Pengawasan Ormas Oleh Pemerintah.

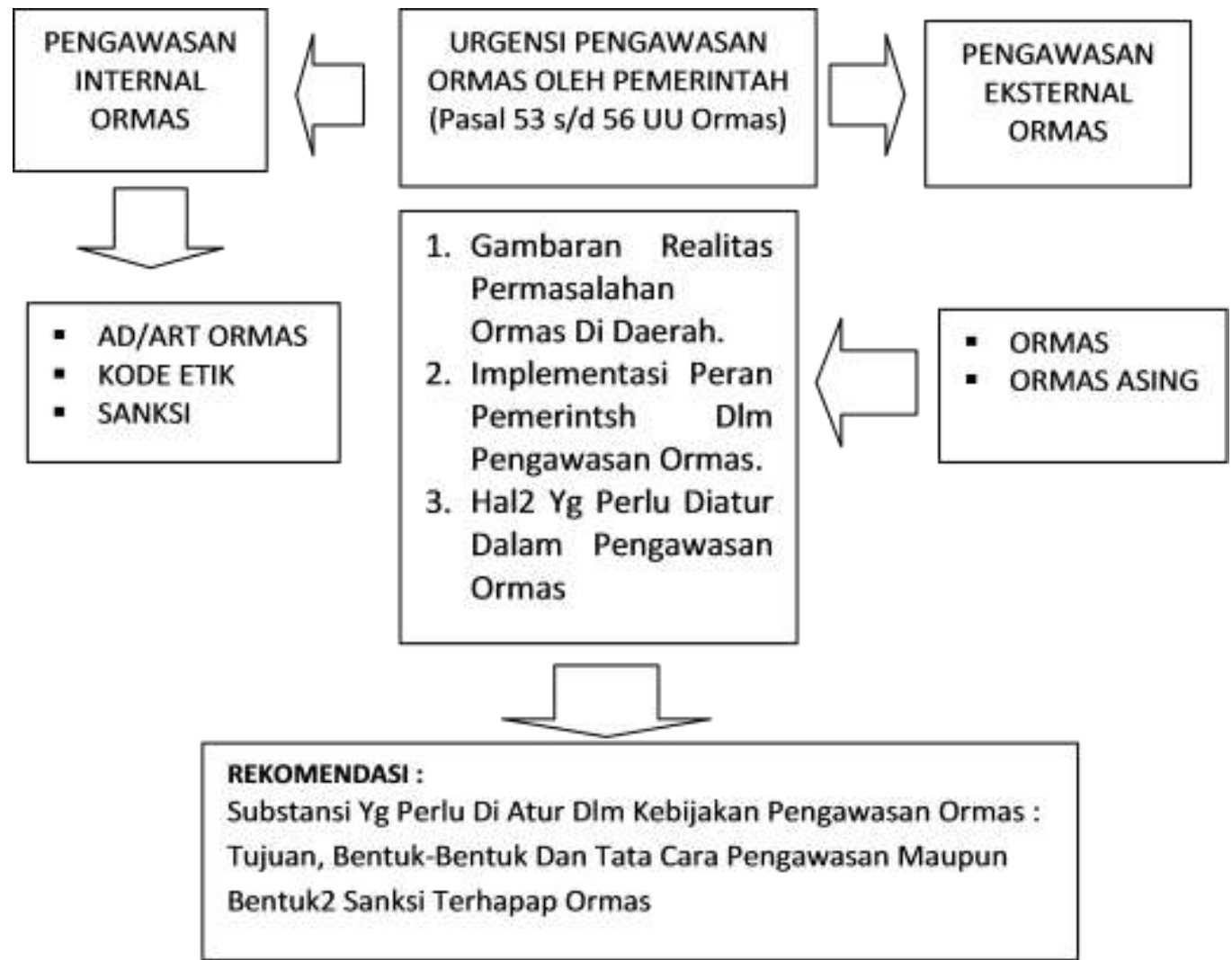

Tidak dapat dipungkiri bahwa kontribusi Ormas dalam penyelenggaraan pemerintahan maupun pembangunan sangat besar. Hal itu telah dibuktikan sejak masa perjuangan kemerdekaan hingga sekarang. Namun juga tidak dapat dipungkiri bahwa masih terdapat sebagian Ormas yang dalam berbagai aktivitasnya justru menimbulkan keresahan dalam masyarakat. Keberadaan Ormas yang semacam itu telah menciptakan kondisi seperti pepatah, karena nila setitik rusak susu sebelanga.

Berdasarkan data yang dapat dikumpulkan dari berbagai sumber baik primer maupun sekunder, dapat ditemukan berbagai fakta mengenai realitas permasalahan Ormas di berbagai daerah. Di Jakarta, bentrokan antar kelompak massa dengan latar belakang etnis kembali terjadi. Pembinaan kelompok massa oleh Pemprov DKI dinilai belum maksimal. Kamis (9/12/2010), di Kawasan Ruko Cempaka Mas, bentrokan terjadi antara kelompok pria berpakaian yang bertulis Forum Betawi Rempug (FBR) dan ormas kepemudaan. Bentrokan dipicu oleh penarikan unit mobil yang cicilannya belum dilunasi. Polisi menyita puluhan senjata tajam setelah berhasil membubarkan bentrokan. Akibat bentrokan, tiga unit mobil yang diparkir di depan kantor PT Oto Multiarta mengalami kerusakan. Kondisi kantor PT Oto Multiarta di blok B 34 terlihat porak poranda akibat serangan dari kelompok massa yang terjadi beberapa jam sebelumnya. Dua mobil diamankan aparat ke Mapolsek Kemayoran sebagai barang bukti untuk proses hukum kasus tersebut.

Tawuran antarormas juga terjadi di Jakarta Pusat. Dua ormas terlibat bentrok di sekitar PRJ Kemayoran, Jakarta Pusat. Kedua ormas tersebut adalah FBR (Forum Betawi Remug) dan PP (Pemuda Pancasila). Hal itu dikemukakan oleh salah seorang petugas piket Polsek Kemayoran, Jakarta Pusat, yang enggan menyebutkan namanya saat dikonfirmasi merdeka.com, Selasa (29/10/2013). Sayangnya petugas tersebut tidak bisa memberi informasi lebih lanjut soal kejadian tersebut. Mengenai kemungkinan jatuhnya korban dan pelaku tawuran membawa senjata tajam atau tidak.

Forum Betawi Rempug (FBR) dan Pemuda Pancasila kembali terlibat bentrok. Kedua ormas itu saling serang di Percetakan Negara, Johar Baru, Jakarta Pusat. Peristiwa tersebut terjadi dari pukul 00.00 WIB sampai pukul 03.00 WIB. Penyebab peristiwa tawuran tersebut belum diketahui, namun diduga karena perebutan lahan. Hal itu disampaikan oleh petugas piket Polsek Cempaka Putih Bripka Budi ketika dihubungi merdeka.com, Selasa (29/10/2013) dini hari. Menurut petugas tersebut, anggota kedua ormas yang terlibat tawuran itu berjumlah sekitar 200 orang. Mereka membawa berbagai senjata tajam berupa golok, celurit dan balok. Namun peristiwa tersebuttidak sampai membawa korban jiwa. Sebelumnya, kedua ormas 
tersebut juga terlibat bentrok di sekitar PRJ Kemayoran, Jakarta Pusat.

Di Depok, Jawa Barat, dua kubu organisasi masyarakat (Ormas) terlibat bentrok di Jalan Cinangka, Sawangan, Depok, malam ini. Peristiwa itu mengakibatkan satu orang terluka karena bacokan senjata tajam. Hal itu disampaikan oleh petugas piket Polres Depok, Aiptu Dadang saat dihubungi merdeka.com, Kamis (24/4/2014). Petugas tersebut menjelaskan bahwa korban yang belum diketahui identitasnya itu sudah dibawa ke Rumah Sakit Umum Daerah (RSUD) Depok. Hingga saat ini kepolisian masih mengamankan lokasi bentrok dua ormas tersebut. Adapun penyebab keributan juga masih diselidiki.

Terkait dengan itu, aparat kepolisian mengamankan 12 orang terkait bentrok antar ormas di Depok, Rabu (23/4/2014) sekitar pukul 21.00 WIB. Selain itu, polisi juga menyita sejumlah senjata tajam di antaranya sebuah golok dan klewang, sebilah samurai, 3 balok kayu, pecahan botol, banner Forum Betawi Rempug (FBR) dan tiga buah sepeda motor. Sebanyak 7 dari 12 orang yang diamankan dikenakan pasal 170 jo pasal 351. Sedangkan 5 orang lainnya dikenakan pasal 170 dan atau pasal 351 jo pasal 55 karena hanya turut serta dan membantu melakukan penganiayaan. Hal itu dijelaskan oleh Kabid Humas Polda Metro Jaya Kombes Rikwanto di Jakarta, Jumat (25/4). Kini, polisi telah melakukan penahanan terhadap 12 orang tersebut.

Sebelumnya, sebuah posko ormas FBR yang terletak di Kecamatan Bojongsari, Depok diserang oleh sekitar 50 orang dari ormas Pemuda Pancasila (PP). Akibatnya, posko FBR pun rusak parah. Tak hanya itu, 3 unit sepeda motor milik anggota FBR tak luput dari amukan massa. Satu anggota FBR mengalami luka di bagian kepala, tangan kiri dan bahu. Kejadian berawal saat sekitar 50 orang anggota PP Pamulang dengan mengendarai sepeda motor bermaksud menanyakan kasus penganiayaan dan pencurian di Polsek Sawangan. Saat berhenti di depan Polsek, puluhan anggota ormas PP tersebut melihat anggota FBR berlari. Mereka pun lantas mengejarnya hingga tiba di posko FBR Bojongsari. Situasi memanas saat salah satu anggota FBR yang tengah berada di posko langsung dibacok dengan golok hingga korban jatuh dan tak sadarkan diri. Puas membacok, puluhan pelaku pun langsung mengarah ke Pamulang yang kemudian dikejar oleh anggota Polsek Sawangan.

Di Karawang, Jawa Barat, tiga unit mobil dan sejumlah sepeda motor rusak akibat bentrok dua kelompok massa dari LSM GMBI dan Ormas BPPKB-Banten di Kabupaten Karawang, Jawa Barat, Sabtu (7/9). Tiga unit kendaraan roda empat atau mobil yang rusak itu, dua di antaranya hangus terbakar. Sedangkan satu unit mobil lainnya hanya rusak pada bagian kaca. Sedangkan sejumlah kendaraan sepeda motor yang berada di sekitar Ormas BPPKB-Banten Jalan Raya Cakradiredja rusak karena dihantam benda tumpul dan dibakar massa. Informasi yang berhasil dihimpun, bentrok antar-LSM dan Ormas tersebut pecah akibat hal sepele, yakni buntut dari permasalahan leasing.

Seperti dilansir dari Antara, seorang petugas leasing itu merupakan anggota Ormas dan kendaraan yang akan ditarik merupakan milik dari salah satu anggota keluarga anggota LSM. Kendaraan itu tidak sempat ditarik. Justru terjadi saling menantang saat itu, sampai memicu emosi masing-masing anggota LSM dan Ormas tersebut. Bentrok yang terjadi pada Sabtu pagi tersebut adalah bentrok susulan yang sempat terjadi pada Jumat (6/9) malam. Pada Jumat (6/9) malam itu sekelompok orang diduga dari Ormas BPPKB-Banten mendatangi sekretariat LSM GMBI, sambil menggerung-gerungkan motor. Selanjutnya, pada Sabtu pagi sekelompok LSM GMBI membalas mendatangi sekretariat Ormas BPPKB-Banten di jalan raya Cakradiredja. Mereka merusak sekretariat dan merusak sejumlah kendaraan di sekitar sekretariat Ormas BPPKB-Banten. Di tempat berbeda, di jalan raya Ahmad Yani Karawang, tepatnya di depan SMA Negeri I, sekelompok massa dari Ormas BPPKB-Banten merusak kendaraan milik LSM GMBI. Aparat kepolisian berusaha menghentikan aksi bentrok susulan dengan memanggil masing-masing pimpinan LSM dan Ormas yang terlibat bentrok tersebut.

Di Denpasar,Bali, dua organisasi masyarakat (Ormas) di Denpasar terlibat bentrok di sekitar Jalan Mahenderadatta, Senin siang. Ratusan petugas kepolisian dari Polresta Denpasar dibantu Polda Bali menjaga lokasi bentrokan. Mulanya terjadi keributan kecil sekitar jam 11.00 Wita, tetapi kemudian berlanjut menjadi lebih besar,kata seorang warga setempat, I Ketut Gede seperti dikutip dari Antara, Senin (14/10). Warga tersebut menceritakan bahwa keributan sempat terhenti namun sejumlah massa kembali berdatangan sekitar pukul 13.00 Wita. Tibatiba massa kembali berdatangan. Mereka membawa senjata berupa pedang dan trisula.Melihat kondisi semakin runyam, warga kemudian menutup pintu kantor sebuah perusahaan mini market yang terletak di sekitar lokasi. Belum diketahui pasti dua ormas yang terlibat keributan termasuk korban luka dan penyebab bentrokan itu.Informasi yang beredar, penyebab bentrok dua ormas tersebut diduga dilatarbelakangi perebutan lahan parkir di sekitar kawasan yang sebelumnya dikenal sebagai Jalan Kargo.Pihak kepolisian sendiri masih terlihat berjaga-jaga di sekitar lokasi. Untuk mengantisipasi hal yang tak diinginkan, petugas kepolisian terpaksa menutup tiga akses jalan di sekitar lokasi di antaranya Jalan Mahenderadatta dan Jalan Gunung Galunggung atau pertigaan Pasar Batukandik, Denpasar.

Di Gianyar, sidang kasus pembunuhan di Pengadilan Negeri Gianyar, Bali terpaksa ditunda. Hal ini terjadi setelah massa dari dua ormas yang saling berseteru terus berdatangan ke Pengadilan. 
Sidang ditunda karena situasi masih memanas, apalagi massa terus berdatangan,kata Ketua Majelis Hakim PN Gianyar Haries Suharman Lubis seperti dikutip dari Antara, Kamis (14/11/2013). Dia meminta massa kedua ormas bisa menahan diri dan mengikuti prosedur hukum yang berlaku. Selanjutnya pihak PN menyerahkan masalah pengamanan lembaga peradilan itu kepada pihak Kepolisian Resor Gianyar. Seharusnya sidang tersebut mengagendakan pemeriksaan saksi-saksi atas terbunuhnya I Gede Wara Widarta alias Gde John (30), warga Dusun Biya, Desa Keramas, Kecamatan Blahbatuh, Kabupaten Gianyar pada bulan Agustus lalu. Korban tewas di pinggir jalan desa itu setelah malam sebelumnya terlibat perkelahian dengan ketiga terdakwa di sebuah warung di Dusun Gelgel, Desa Keramas. Diduga perkelahian yang berbuntut pada pembunuhan tersebut dipicu oleh perbedaan korban dan pelaku terkait keanggotaan di dua ormas yang saling berebut pengaruh di Bali itu. Ketiga pelaku, yakni Wayan Wiradnyana, Made Juniadi, dan Wayan Sudiarta disidangkan dalam satu berkas perkara nomor 168/PID.B/2013/PN.Gir. Seorang pelaku lainnya, Wayan Sudarsana, disidangkan dalam berkas perkara nomor 167/PID.B/2013/PN.Gir. Sebelum menuju PN Gianyar, massa kedua ormas sempat berkumpul di Terminal Kebo Iwa. Namun petugas kepolisian segera turun tangan untuk menghindari kontak fisik antar anggota kedua ormas tersebut.

Di Medan, anggota dua organisasi kepemudaan, Pemuda Pancasila (PP) dan Ikatan Pemuda Karya (IPK), bentrok di Jalan Merak Jingga dan Jalan Gaharu, Medan, Kamis (26/9/2013). Sedikitnya dua orang terluka dalam peristiwa ini, sedangkan 14 lainnya diamankan ke kantor polisi. Bentrok pertama terjadi saat sekelompok anggota PP Pimpinan Anak Cabang (PAC) Medan Perjuangan melintas di Jalan Putri Merak Jingga, sekitar pukul 16.00 WIB. Mereka lewat jalan itu setelah melakukan aksi demonstrasi di Belawan. Saat melintas, bus yang ditumpangi anggota Pengurus Anak Cabang (PAC) PP Medan Perjuangan dihadang sekelompok pemuda menghunus senjata tajam, beberapa di antaranya dikenali sebagai anggota IPK. Bus itu dilempari kelompok penghadang dengan batu. Sempat terjadi perlawanan, namun massa PP mundur hingga ke depan Kantor KPU Sumut.

Sempat terjadi bentrokan selama setengah jam, tapi karena kalah personel, akhirnya salah satu kelompok kemudian menarik anggota untuk mencari kekuatan tambahan. Hal itu disampaikan oleh Ketua PAC PP Medan Perjuangan Barri Siregar selaku salah satu pihak yang terlibat bentrokan. Pemicu bentrokan adalah karena mereka tidak terima dengan perlakuan anggota IPK. Ketika anggota PP mau pulang tapi mereka (IPK) malah menyerang. Akibatnya, satu anggota PAC yang diketahui bernama Iwan terkena lemparan batu dan terpaksa dilarikan ke RS Pringgadi.
Sementara itu, Wakil Ketua IPK Medan Barat Arie Popay justru menuding kejadian itu dipicu anggota PP dari Gaharu yang lebih dulu melintas di sana. Dia menuding, kelompok pertama ini turun dari bus dan menyerang masuk ke dalam kantor IPK untuk melakukan penjarahan. Menurut Arie, anggota PP yang mulai. Ketika kami (anggota PP) duduk, mereka datang dan masuk ke dalam pos IPK , istri saya sempat berteriak, 'jangan diambil TV kami'. Karena jumlah kami sedikit, kami lari, untuk mengumpulkan personel, katanya. Setelah berkumpul, kata dia, anggota IPK berjaga-jaga di lokasi kejadian. "Pas pula lewat bus kedua dari PAC Medan Perjuangan, jadi kami halau. Tidak terima, mereka turun dan menyerang kami, makanya terjadinya bentrokan ini. Jadi, bukan kami yang memulai," katanya.

Ketegangan sempat reda sekitar pukul 17.30 WIB. Saat itu, anggota PP yang terkonsentrasi di depan kantor KPU Sumut memilih berkumpul di kantor PAC PP Medan Timur. Namun, sekitar pukul 18.00 WIB bentrok susulan terjadi di Jalan Gaharu, Medan. Saat itu, anggota PP bentrok dengan anggota IPK dan warga setempat. Polisi yang telah bersiaga di kawasan itu pun bertindak cepat dan membubarkan massa yang bentrok. Mereka mengamankan 14 orang yang kedapatan membawa senjata seperti pisau, besi dan juga stick golf. Ke-14 orang ini diboyong ke Mapolresta Medan untuk pemeriksaan lebih lanjut. Di Mapolresta Medan, mereka didata. Sementara itu dua orang yang terluka dilarikan ke RSU Pirngadi Medan untuk mendapat pengobatan

Fakta-fakta lapangan di atas menunjukkan bahwa masih banyak ormas yang melakukan tindakan-tindakan anarkis yang hanya mengedepankan emosi dan tidak sesuai dengan peraturan perundang-undangan yang berlaku. Dengan masih terjadinya bentrokan tersebut, menurut Anggota Komisi A DPRD DKI, Abdul Aziz, menunjukkan bahwa pembinaan terhadap Ormas masih belum maksimal. Berbagai peristiwa bentrokan antar ormas yang berapa kali terjadi menunjukkan bahwa pembinaan terhadap Ormas masih belum maskimal. Jadi kewajiban pemerintah provinsiuntuk meningkatkan pembinaan ke semua ormas. Hal itu dikemukakan oleh anggota Komisi A DPRD DKI, Abdul Aziz kepada detikcom, Kamis (9/12/2010). Menurut Abdul seharusnya segala tindakan yang dilakukan oleh kelompok massa bisa dideteksi sehingga dapat dilakukan pencegahan. Hal itu dapat dilakukan jika pola pembinaan berjalan dengan baik. Pola pembinaan hakikatnya dapat dilakukan melalui bermacam bentuk. Antara lain, agar mereka mendapat pekerjaan yang layak, dilakukan pembinaan pelatihan keterampilan. Abdul sepakat jika ada ormas yang sering bertindak anarkis perlu dibubarkan. Meski begitu, mekanisme pembubaran perlu merujuk pada UU Nomor 8 Tahun 1985 tentang Organisasi Kemasyarakatan (ormas), 
sehingga Pemerintah seharusnya tidak membiarkan organisasi yang memiliki track record tidak baik bebas seenaknya.

Dalam berbagai kasus, seringkali ada oknum anggota organisasi masyarakat (ormas) yang bertindak melanggar hukum. Agar kiprah seluruh anggota ormas tidak menabrak aturan, ormas harus memiliki mekanisme pengawasan internal. Ketentuan ini juga berlaku untuk ormas yang didirikan warga negara asing. Direktur III Ditjen Kesbangpol Kemendagri, Budi Prasetyo mengatakan, di Undang-undang Nomor 17 Tahun 2013 tentang Ormas, ada bab khusus yang mengatur mengenai pengawasan ormas. "Tujuannya untuk meningkatkan kinerja dan akuntabilitas ormas," terang Budi kepada wartawan di Jakarta, kemarin.

Pemerintah akan memperkuat perannya dalam mengawasi keberadaan organisasi massa. Menurut Menteri Dalam Negeri Gamawan Fauzi, kedepan seluruh Ormas harus mendaftarkan organisasinya ke Kementerian Dalam Negeri. Mendagri mengungkapkan bahwa jika Ormas tidak terdaftarpemerintah akan minta kepolisian memberikan izin setiap kegiatan mereka. Selain itu, Ormas tidak bisa mendapatkan fasilitas kerja sama dengan instansi pemerintah, termasuk bantuan dana untuk kegiatan. Dia menambahkan, dalam pembahasan revisi RUU Ormas, pemerintah mempunyai fungsi untuk mengatur keberadaan Ormas. Selama ini menurut Mendagri, ormas-ormas bisa berdiri hingga mencapai 64 ribu Ormas dan beroperasi seenaknya tanpa ada aturan yang membatasi. Meski demkian, dia menandaskan, pengaturan ini bukan berarti membuat pemerintah menjadi otoriter.

Kelompok preman berbalut organisasi masyarakat masih kerap dimanfaatkan untuk kepentingan politik. DPR meminta pemerintah yang mengeluarkan badan hukum organisasi tersebut menyeleksi dan mengawasi perjalanan organsasi itu. Menurut Anggota Komisi III DPR dari PKS Indra, upaya selektif terhadap pembentukan setiap organisasi masyarakat harus dlakukan. Namun, yang lebih penting adalah bagaimana setelah organisasi itu berdiri, pemerintah melakukan pengawasan. "Kalau saat pendirian memang itu bisa diakali ya oleh pendiri ormasnya. Tapi saat organisasi terbentuk, pemerintah harus melakukan pengawasan, pembinaan, dan penegakan hukum bagi ormas itu," kata Indra saat dihubungi ROL, Selasa (12/3/2013). Indra mengatakan, jika ternyata dalam pengawasan organisasi masyarakat tersebut bermasalah dan menimbulkan keresahan masyarakat, maka pemerintah berhak melakukan tindakan. Yaitu, dengan cara mencabut izin operasi ormas tersebut. "Semua organisasi ya, tanpa pengecualian," kata Indra.

Menanggapi pernyataan Indra tesebut, Kepala Subdirektorat Ormas Kemendagri, Bahtiar mengatakan, saat pada saat pendirian ormas dan pengajuan izin ke pemerintah, semua organisasi masyarakat memiliki tujuan yang baik. Mereka pada umumnya bertujuan untuk kegiatan kemanusiaan, kebangsaan, dan pendidikan. "Maka dari itu kita kabulkan. Karena negara kan tidak melarang warga negara untuk berkumpul dan berserikat," kata Bahtiar kepada ROL, Selasa (12/3/2013). Namun, pada saat pengawasan, pihaknya kesulitan. Karena, tak undang-undang yang mengatur jelas tentang pengawasan terhadap organisasi masyarakat. Yang ada adalah pengaturan tentang pendirian dan pembubaran. "Hampir semua undang-undang tak ada aturan yang tegas bagaimana seharusnya LSM atau organisasi masyarakat berperilaku di ruang publik" katanya. Karena itu, Bahtiar berpendapat pentingnya RUU Ormas disahkan menjadi undang-undang. Karena, dalam RUU tersebut diatur secara jelas mengenai hak dan kewajiban sebuah organisasi masyarakat.Dengan adanya dasar hukum tersebut, pemerintah bisa dengan tegas mengawasi perilaku setiap organisasi masyarakat.

Kepala Badan Kesatuan Bangsa dan Politik (Kesbangpol) Provinsi Banten Ubaidilah akan memperketat pengawasan lembaga kemasyarakatan seperti organisasi mayarakat (ormas), Lembaga Swadaya Mayarakat (LSM) maupun yayasan. Pengawasan yang akan dilakukan oleh Kesbangpol yaitu dengan melakukan data verifikasi, baik secara adminstratif maupun faktual, atau langsung meninjau ke lapangan. "Kami akan awasi terus keberadaan lembaga kemasyarakatan tersebut, mulai dari kegiatan sampai mengaudit keuangannya," ujar Ubaidilah, akhir pekan kemarin.

Dikatakannya, saat ini lembaga kemasyarakatan yang tercatat di Kesbangpol Provinsi Banten jumlahnya mencapai 700, terdiri dari 280 LSM, 300 Ormas, dan sisanya adalah yayasan. Menurut Ubaidilah, jumlah tersebut terus mengalami peningkatan setiap tahunnya."Saya tidak tahu persis berapa persen jumlah kenaikannya, namun yang jelas peningkatan tersebut bukan karena persyaratan mendirikan lembaga kemasyarakatan itu diperlonggar," ujar dia, seraya menambahkan bahwa kesbangpol juga tidak membatasi jumlah organisasi kemasyarakatan, selama dalam pendiriannya tidak menyalahi aturan.

Mengenai banyaknya lembaga kemasyarakatan yang sering melakuan aksi demonstrasi, bahkan sampai anarkis, Ubaidilah mengatakan itu merupakan tupoksi dari aparat kepolisian. Terpenting, LSM atau Ormas harus mempunyai izin dari Kesangpol ketika akan melakukan aksi tersebut."Kami juga akan terus melakukan sosialisasi beserta penyuluhan ke setiap lembaga, agar hal-hal yang diresahkan masyarakat tidak terus berulang," tegasnya.Ditambahkan, upaya lain dalam menyiasati tidak adanya lembaga masyarakat yang bodong, dalam waktu dekat Kesbangpol juga merilis daftar-daftar nama lembaga itu kepada masyarakat umum."Masyarakat jelas harus mengetahui mana saja lembaga yang ilegal dan 
mana yang mempunyai SK dari kami. Mudahmudahan dengan cara ini, tidak ada lagi oknum yang memanfaatkan keberadaan lembaga kemasyarakatan ini," pungkasnya.

Dalam Undang-Undang (UU) baru No. 17 Tahun 2013 tentang Ormas, Organisasi Masyarakat (Ormas) anarkis atau mengganggu ketertiban dan keamanan bisa dibekukan atau dibubarkan. Saat ini, hal tersebut sedang ditelaah oleh Kantor Kesatuan Bangsa dan Politik (Kesbangpol) Kabupaten Tangerang sebelum disosialisasikan. "Kami sedang menelaah UU baru Nomor 17/2003 tentang Ormas yang mengganti UU Nomor 8/2005 sebagai payung hukum sebelumnya. Dalam UU baru ini ditegaskan Ormas dilarang melakukan tindakan anarkisme atau mengganggu kemanan dan ketertiban," kata Tisna Hambali Kepala Kantor Kesbangpol Kabupaten Tangerang. Lanjut Tisna, dalam UU ini juga tidak hanya pemerintah daerah yang melakukan pengawasan Ormas tetapi juga masyarakat umum. "Jika Ormas tersebut melakukan aksi anarkisme bisa diberlakukan pencabutan surat keterangan, pemberhentian bantuan, pembekuan atau pembubaran Ormas. Nah, pemerintah daerah bisa mengambil langkah sanksi tersebut, sesuai hirarki,'tandas Tisna.

Maksud sesuai hirarki tersebut kata Tisna, yakni untuk presiden yakni Ormas ditingkatan nasional dan provinsi. Agar Ormas tidak terjerumus pada tindakan anarkisme, Kebangpol gencar menggelar bimbingan teknis, dengan melibatkan LSM. "Kami ingin merubah orientasi Ormas tidak hanya pembentukan saja, tetapi juga dituntut kejelasan dalam pendiriannya, seperti membuat AD/ART, membuat kegiatan spesifik sebagai programnya," ungkap Tisna. Tisna mengungkapkan, hingga saat ini ada 213 jumlah Ormas di Kabupaten Tangerang. Ormas tersebut dibagi dalam beberapa kriteria. Yakni Ormas yang mempunyai AD/ART dan disahkan notaris, serta didaftarkan ke kementerian kehakiman. "Itu sudah sah meski tidak daftar ke pemerintah daerah. Kalau tidak memiliki AD/ART dan tidak terdaftar, camat wajib mendata dan camat berhak melakukan pendataan Ormas tidak berbadan hukum," tegasnya. Menurut Tisna, maksud dari Ormas yakni setiap tiga orang yang berkumpul dan mendirikan organisasi lebih dari tiga orang disebut dengan Ormas, baik dinamakan serikat, perhimpunan, federasi, aliansi dan lainnya. "Ya UU Ormas yang baru ini agar menjadi perhatian bagi semua Ormas," pungkasnya.

Kasubbid Ketahanan seni dan budaya kesbangpol Kalsel Said Abubakar mengatakan keberadaan 141 ormas dan LSM di Kalsel memiliki peran yang penting dan strategis untuk melakukan kontrol sosial terhadap berbagai permasalahan yang timbul dimasyarakat. Namun dikhawatirkan kecenderungan adanya ormas dan LSM yang beraktivitas diluar jalur dan bahkan melanggar hukum. Said Abubakar menambahkan pihaknya tidak ragu untuk melakukan konsultasi dan teguran kepada ormas atau LSM yang dinilai sudah menyimpang.

Sejalan dengan implementasi UU No. 17 Tahun 2013 tentang Organisasi Kemasyarakatan, masyarakat sipil mulai merasakan dampaknya. Di lapangan, aparat pemerintah telah mulai menjalankan aturan UU Ormas secara konsisten. Akibatnya, yang paling merasakan dampaknya adalah lembaga swadaya masyarakat (LSM) dan Serikat Pekerja (SP). Berdasarkan pemantauan Koalisi Kebebasan Berserikat (KKB) selama enam bulan terakhir dampak negatif UU Ormas mulai kelihatan. Sejumlah LSM diancam yang kritis kepada pemerintah daerah setempat diancam dibubarkan, dan ada SP yang tak diperkenankan ikut dalam forum ketenagakerjaan. Koordinator KKB, Fransisca Fitri, menjelaskan ada LSM dan SP yang diancam dibekukan, bahkan diduga ilegal. Ancaman itu muncul di Lombok Utara, Bandung Barat, Lombok Tengah, dan Sumatera Utara. Forum Indonesia untuk Transparansi Anggaran (Fitra) Sumatera Utara misalnya. Forum ini berbentuk yayasan sehingga tunduk pada UU Yayasan. Oleh karena itu Fitra tidak dilayani ketika minta informasi dengan alasan tidak terdaftar di Kesbangpol Linmas. Di Lombok Tengah Kesbangpol mengancam membubarkan Konsorsium Lombok Tengah karena tidak punya izin, papan nama, dan kantor. Konsorsium ini dianggap ilegal meskipun selama ini konsorsium menjadi mitra pemda setempat. Ketika UU No.17 Tahun 2013 tentang Ormas diterapkan, maka mereka dianggap ilegal. Hal itu dijelaskan Fitri dalam jumpa pers yang digelar KKB di Jakarta, Kamis (13/3).

Lain pula yang dialami salah satu SP di Kabupaten Singkil, Nanggroe Aceh Darussalam. SP yang tergabung dalam Konfederasi Serikat Pekerja Indonesia (KSPI) tidak dapat menempati posisi sebagai anggota Lembaga Kerja Sama Tripartit Daerah. Sebab, dianggap tidak mendapat persetujuan dari Kesbangpol Pemda setempat. Fitri berpendapat peristiwa serupa bakal terus terjadi karena UU Ormas membuka peluang terjadinya hal tersebut. Pasalnya, ketentuan yang tercantum dalam UU Ormas sangat luas sehingga dapat ditafsirkan berbeda-beda oleh aparat di lapangan. Misalnya, ketentuan pendaftaran kepada seluruh ormas ke Kesbangpol tidak disebut secara tegas dalam UU Ormas. Namun praktiknya di lapangan, Kesbangpol di daerah menganggap pendaftaran Ormas itu wajib. Sehingga Ormas yang tidak mendaftar ke Kesbangpol dituduh ilegal dan dapat dibubarkan.

\section{Implementasi Peran Pemerintah (termasuk Pemerintah Daerah) dalam melakukan Pengawasan terhadap Ormas.}

1. Keberadaan Ormas dan Pentingnya UU Ormas. Peran masyarakat sipil dalam konteks pembangunan bangsa sangatlah vital. Peran 
masyarakat sipil di Indonesia dalam proses pembangunan, baik secara fisik maupun pembangunan sumber daya manusia, sudah terbukti dalam sejarah perjuangan bangsa.(Jeirry Sumampow, 2011) Bahkan, dapat dikatakan bahwa tanpa organisasi masyarakat (Ormas) maka kemerdekaan Indonesia akan sulit diwujudkan ketika ituSejarah bangsa mencatat peran yang sangat penting dimainkan organisasi masyarakat, seperti; Boedi Oetomo (1908), Syarikat Dagang Islam (1911), Muhammadiyah (1912), Nahdlatul Ulama (1926), organisasi-organisasi pemuda kedaerahan (Jong Java, Jong Celebes, Jong Ambon, dll./1918), organisasi kependidikan, dll, dalam perjuangan pencerdasan anak bangsa menuju Proklamasi Kemerdekaan Bangsa Indonesia 17 Agustus 1945.

Namun demikian, sejarah bangsa kita juga mencatat pasang-surutnya peran Ormas seiring dengan dinamika sosial-politik yang muncul dalam sejarah perjalanan bangsa. Masa keemasaan Ormas dalam pemberdayaan dan pencerdasan rakyat sebelum kemerdekaan, terutama di bidang pendidikan, agak surut seiring dengan meningkatnya perjuangan bersenjata ketika masa perang untuk merebut kemerdekaan. Pada awal kemerdekaan, peran Ormas kembali bangkit dengan maraknya pembentukan organisasi-organisasi kemahasiswaan yang mencapai puncaknya hingga tahun 1970-an. Peran Ormas kembali mengalami kemunduran dengan menguatnya pemerintahan Orde Baru yang cenderung bersikap represif terhadap perbedaan ide dan gagasan serta sikap kritis terhadap kebijakan pembangunan. Kontrol dan pembungkaman suara kritis Ormas serta penghilangan aktivis Ormas yang kritis terhadap kebijakan Pemerintah Orde Baru ketika itu lalu diperkuat dengan munculnya UU No. 8 Tahun 1985 tentang Ormas. Ketika itu, UU No. 8 Tahun 1985 memang dimaksudkan untuk meredam suara-suara kritis Ormas terhadap kebijakan pemerintah Orde Baru yang sudah semakin jauh dari kepentingan rakyat banyak. Ormas yang tak mau mengikuti kehendak Pemerintah dapat dengan segera dibubarkan secara sepihak oleh Pemerintah.

Pada periode pertama pembangunan Orde Baru, prioritas pembangunan ekonomi dan stabilitas sistem kekuasaan merupakan prioritas utama yang dijalankan oleh Presiden Soeharto. Akibatnya seringkali terjadi ketegangan antara Negara dengan masyarakat yang menuntut keseimbangan proses pembangunan, transparansi serta akuntabilitas dari pemerintah. Gerakan-gerakan tersebut kemudian melahirkan organisasi-organisasi non pemerintah dan organisasi kemasyarakatan yang secara aktif memperjuangkan dan bergerak di bidang hak asasi manusia, pemberdayaan masyarakat, perlindungan terhadap buruh, dan advokasi lingkungan (Elsam, 2013). Setelah Orde Baru tumbang yang menandai bergulirnya Era Reformasi pada tahun 1998, Ormas kembali bergairah. Pertumbuhan Ormas menjadi sangat pesat dari segi jumlah, ragam kegiatan dan fokus bidang perhatian berdasakan visi, misi dan tujuan masing-masing. Perannya pun terasa menjadi semakin signifikan dalam konteks pembangunan bangsa, khususnya dalam hal pemberdayaan dan pencerdasan rakyat, karena meliputi bidang yang sangat luas dan beragam, seperti bidang sosial, keagamaan, profesi, pemberdayaan ekonomi, lingkungan, anti korupsi, penguatan demokrasi, perlindungan TKI, pemberdayaan perempuan, dll. Kebebasan dan keterbukaan yang diberikan membuat Ormas mampu secara bebas melakukan kontrol dan pengawasan terhadap kebijakan dan kinerja pemerintahan dan parlemen.

Maraknya Ormas di era refromasi setidaknya disebabkan oleh 3 hal, yaitu: 1) Tersedianya ruang yang lebih terbuka bagi aktualisasi peran Ormas dalam pemberdayaan masyarakat maupun sebagai mitra kritis (kontrol) terhadap kebijakan-kebijakan pemerintah. 2) Terjadinya perubahan paradigma dalam memandang Ormas, khususnya di kalangan pemerintah. Kalau dulu Ormas dilihat sebagai "ancaman" atau "lawan", maka sejak Reformasi Ormas dilihat sebagai mitra yang penting dalam pelaksanaan pembangunan nasional. 3) Semangat filantropi masyarakat Indonesia yang relatif tinggi untuk memberi kontribusi bagi pembangunan bangsa.

Dalam perkembangannya, Ormas mempunyai peranan yang sangat penting dalam meningkatkan keikutsertaan secara aktif seluruh lapisan masyarakat dalam rangka menjamin pemantapan persatuan dan kesatuan bangsa, menjamin keberhasilan pembangunan nasional, dan menjamin tercapainya tujuan nasional. Peran individu untuk dapat berpartisipasi secara efektif di dalam demokrasi sangat erat kaitannya dengan pengembangan pribadi yang berasal dari konsep kewarganegaraan yakni dalam suatu tatanan yang demokratis sebagai pengembangan moral yang memperoleh perasaan tanggung jawab yang lebih matang setiap tindakan individu tersebut. Setiap individu harus menikmati suatu tingkat otonomi pribadi yang tinggi didalam keputusan perseorangan dan bersama, dan berkaitan erat dengan pengembangan diri agar individu dan masyarakat secara sekaligus berkembang kearah kehidupan bersama yang terus meningkat.

Ormas sebenarnya memiliki peran yang cukup besar dalam sebuah kehidupan bernegara. Hal ini karena keberadaan masyarakat sipil adalah prasyarat mutlak bagi demokrasi yang bukan hanya berlaku di tingkat masyarakat bernegara, tetapi juga di tingkat terbawah dari setiap strata sosial (Adi Suryadi, 2006). Apa yang telah dilakukan oleh ormasselama ini menunjukkan bahwa Ormas selalu mampu mempertahankan otonominya dan selalu menunjukkan sikap kritis terhadap negara dan juga kelompok masyarakat lainnya, sehingga mampu menjadi kekuatan penyeimbang dalam kehidupan bernegara. Hal ini sejalan dengan fakta bahwa masyarakat sipil juga melakukan upaya-upaya 
penguatan kapasitas, pemberdayaan masyarakat, monitoring kinerja pemerintah, hingga advokasi. Sumber pendanaan Ormas juga seringkali bersifat mandiri, dalam arti tidak menggunakan sumbersumber pendanaan dari negara.

Sejalan dengan perkembangannya, keberadaan Ormas dalam melakukan aktivitasnya memerlukan jaminan untuk bebas berserikat, berkumpul, mengeluarkan pendapat serta kesempatan yang sama. Jaminan perlindungan tersebut pada hakikatnya merupakan tanggung jawab negara yang dituangkan dalam sebuah peraturan untuk melindungi masyarakat dalam menjalankan kebebasan berserikat dan berkumpul. Oleh karena itu keberadaan aturan mengenai Ormas dipandang penting. Meningkatnya jumlah Ormas yang berlangsung sejak jatuhnya Soeharto pada 1998 dan munculnya Ormas-ormas anarkis yang melakukan kekerasan, ormas-ormas yang membahayakan keamanan dan kepentingan negara, serta ormasormas yang mendapatkan dukungan finansial negara asing sehingga dianggap mewakili kepentingan asing, menimbulkan kekhawatiran akan terganggunya stabilitas dan ketertiban umum.

Ada tiga motif akar persoalan, sehingga ormas itu melakukan tindakan anarkis. Pertama, bermotif agama, teologis, dan keyakinan. Kedua, bermotif politik yang dipakai orang-orang tertentu untuk kepentingan pribadi. Dan ketiga, bermotif ekonomi. Ketiga motif inilah yang barangkali melatarbelakangi ormas itu berbuat anarkis.Aksi-aksi kekerasan yang dilakukan ormas ini dikhawatirkan akan memecah belah persatuan yang telah terjalin di Indonesia. Di lain pihak, Kemendagri yang bertugas untuk mengawasi keberadaan ormas-ormas ini kesulitan untuk mengawasi dan melakukan pembinaan. Terlebih saat ini masih banyak ormas yang belum terdaftar resmi di Kemendagri, sehingga Kemendagri kesulitan untuk memberikan sanksi terhadap ormas-ormas yang melanggar ketentraman dan keamanan. Sementara itu, beberapa aturan yang ada ternyata kurang efektif sebagai sarana untuk menindaknya. Karena itu maka UU No. 17 Tahun 2013 tentang Organisasi Kemasyarakatan merupakan salah satu kebijakan Negara untuk menertibkan organisasi-organisasi kemasyarakatan yang selama ini dianggap tidak mentaati tertib hukum Indonesia, khususnya yang berkaitan dengan hak dan kebebasannya dalam berserikat, berkumpul dan menyampaikan pendapat.

Kelahiran UU No. 17 Tahun 2013 justru menempatkan Ormas sebagai subyek agar ormas lebih mandiri, berdaya dan berkontribusi positif dalam pembangunan bangsa. UU ormas adalah pengakuan dari negara untuk mereka. UU Ormas juga merupakan jawaban negara atas kebutuhan publik untuk mengembangkan kreativitas dan apresiasinya terhadap keberadaan Ormas. UU Ormastidak untuk membatasi tapi mengatur.
Agar implementasi UU Ormas dapat segera dilaksanakan, maka Pemerintah menerbitkan enam Peraturan Pemerintah (PP) PP terkait UU Organisasi Kemasyarakatan (Ormas). Adapun tiga PP yang sudah siap antara lain adalah PP Pendaftaran Ormas, PP Pemberdayaan dan PP Tata Cara Penyelenggaran Izin Operasional Ormas. Ketiga PP akan diterbikan sekaligus dalam waktu dekat. Pemerintah sudah melakukan persiapan. Hal itu dikemukakan oleh kata Dirjen Kesbangpol Kementerian Dalam Negeri (Kemendagri) Tanribali Lamo dalam diskusi Sosialisasi UU Ormas bersama mantan Wakil Ketua Pansus RUU Ormas, Deding Ishak (F-PG), Dirjen Perundang-Undanga Kemenkum-HAM, Wahidudin Adam dan Direktur Sosial Budaya Organisasi Internasional Negara Berkembang, Dirjen Multilateral Kemenlu Arko Hananto B, di Jakarta, Selasa, (23/7/2013). Menurut Dirjen Kesbangpol, sekitar tiga PP lainnya masih dalam kajian, antara lain PP soal Sistem Informasi, PP Tata Cara Pengawasan dan PP Penjatuhan Sanksi.

Menurut Dirjen Kesbangpol, ada sejumlah perbedaan mencolok antara UU No 88 Tahun 1985 pada jaman Orba dengan UU Ormas yang baru saja disahkan. Pada UU ormas lama, lebih kental dengan kata pembinaan. Dimana aspek pembinaan ini lebih bernuansa intervensi pemerintah. Sedangkan UU Ormas baru ini, asasnya hampir sama dengan partai politik dan pemerintah tak bisa melakukan intervensi.

Sementara itu, mantan Wakil Ketua Pansus RUU Ormas, Deding Ishak mengakui, UU Ormas yang baru disahkan ini lebih maju dibandingkan dengan UU Ormas yang lama, yakni UU No. 8 Tahun 1985.Era reformasi secara langsung menunjukkan kelemahan UU No. 8 Tahun 1985 dan karena itu dipandang penting untuk direvisi. Ada beberapa kelemahan UU tersebut yang menjadi alasan kenapa penting untuk dilakukan revisi, yaitu sebagai berikut:

Pertama, adanya perubahan paradigma dalam mengelola negara, dari orientasi elit political base berubah tekanan ke community base. Akibatnya, UU No. 8 Tahun 1985 yang disusun dengan paradigma sentralistik tak lagi cocok dengan model pemerintahan yang cenderung desentralistis. Begitu juga, nuansa kontrol dan pengendalian Ormas yang sangat kental dalam UU No. 8 Tahun 1985 tentu juga tak lagi relevan dengan spirit pemberdayaan dan kemitraan kritis antara Pemerintah dan Ormas yang menjadi tuntutan reformasi. Dan, gaya pemerintahan yang otoritarianis dan represif model Orde Baru tak lagi memiliki tempat dalam iklim demokrasi yang menjadi syarat utama pengelolaan pemerintahan di zaman Orde Reformasi ini.

Kedua, reformasi menuntut pengelolaan negara berdasarkan prinsip-prinsip akuntabilitas, partisipatif dan transparansi. Nilai-nilai ini bertentangan dengan prinsip-prinsip pengaturan 
Ormas yang tertuang dalam isi UU No. 8 Tahun 1985.

Ketiga, peran Ormas sebagai social capital dalam pengembangan civil society tidak lagi sekadar sebagai alat untuk melegitimasi kebijakan-kebijakan pemerintah seperti yang terjadi dulu. Tidak lagi hanya sebatas "tukang stempel" kebijakan pemerintah.

Keempat, perlu melakukan harmonisasi dan sinkronisasi dengan UU lain, khususnya UU yang lahir di era reformasi, agar langgam gerak Ormas seirama dengan pembangunan demokrasi secara menyeluruh. Dan, sejalan dengan hal ini, dinamika Ormas saat ini memang memerlukan bentuk hukum baru sebagai landasan untuk menjalankan perannya bagi pembangunan masyarakat.

Dalam UU Ormas yang baru, Pancasila dijadikan sebagai ideologi. Sehingga Pancasila tidak ditafsirkan secara sepihak, makanya kita sepakat dengan empat pilar. Menurut Deding, UU Ormas ini tidak anti demokrasi, karena itu sama sekali tidak memberikan ruang terhadap pemerintah untuk melakukan intervensi. Karenanya ada beberapa ayat dan pasal yang sempat dihilangkan, sehingga UU Ormas yang baru sangat berbeda jauh dengan UU No. 8 Tahun 1985. Perubahan yang signifikan pada UU Ormas yang baru memang untuk menjawab berbagai kecemasan dan kekhawatiran yang terjadi di masyarakat. Hal ini terkait dengan penolakan masyarakat sipil. Dalam hal ini, ormas dimasukan sebagai objek. Jadi masyarakat takut, bahwa pemerintah masih bisa bertindak secara otoriter.Yang jelas, dengan pengesahan UU ormas ini, maka tugas DPR sudah selesai. Tinggal bagaimana melakukan langkah-langkah untuk sosialisasi ke masyarakat.

Secara lebih rinci, menurut Dirjen Kesbangpol Kementerian Dalam Negeri, beberapa perubahan mendasar dalam Undang-Undang Nomor 17 Tahun 2013 antara lain adalah:

1) Asas Ormas, tidak lagi menempatkan Pancasila sebagai satu-satunya asas (asas tunggal).

2) Adanya pembagian kewenangan yang jelas dalam memberikan pelayanan ormas. Adanya kemudahan dengan menyediakan pilihan layanan kepada Ormas, yaitu untuk ormas yang berbadan hukum (yayasan dan perkumpulan) oleh Menteri Hukum dan HAM, sedangkan yang tidak berbadan hukum oleh Menteri Dalam Negeri, Gubernur, Bupati/Walikota sesuai dengan lingkup ormas. Untuk ormas yang didirikan warga negara asing dan badan hukum asing harus mendapat ijin prinsip dari Kementerian Luar Negeri dan ijin operasional dari Kementerian/Lembaga.

3) Mendorong tata kelola keuangan ormas dilakukan secara transparan dan akuntabel.

4) Pemberdayaan dilakukan dengan menciptakan iklim dan suasana yang memungkinkan ormas dapat tumbuh berkembang secara sehat, menguatkan kapasitas kelembagaan, dan meningkatkan kualitas sumberdaya ormas. Pemberdayaan bertujuan untuk menjaga keberlangsungan hidup dan mendorong kemandirian ormas. Pemberdayaan tidak saja dilakukan oleh pemerintah dan pemda tetapi bisa melalui partisipasi swasta maupun masyarakat luas.

5) Pengaturan hak, kewajiban dan larangan diperlukan untuk memberi batasan apa yang boleh dan tidak boleh dilakukan oleh Ormas diruang publik. Larangan dibuat semata-mata untuk menciptakan tertib sosial, melindungi kepentingan publik, melindungi hak asasi warga masyarakat lainnya serta menjaga keutuhan dan kedaulatan negara kesatuan Republik Indonesia.

6) Adanya mekanisme penyelesaian sengketa Ormas baik dilakukan secara internal, melalui mediasi pemerintah maupun melalui pengadilan.

7) Pemberian sanksi tidak lagi menjadi kewenangan subyektif pemerintah. Pembubaran terhadap ormas berbadan hukum hanya dapat dilakukan setelah adanya putusan pengadilan yang berkekuatan hukum tetap, sedangkan sanksi pencabutan Surat Keterangan Terdaftar bagi ormas yang tidak berbadan hukum harus mendapat fatwa dari Mahkamah Agung.

8) UU Ormas ini juga sangat memperhatikan aspek sejarah, dengan memberikan pengakuan dan penghormatan sebagai aset bangsa kepada ormasormas yang telah lahir sebelum kemerdekaan 17 Agustus 1945, sebagai wadah perjuangan dan pergerakan masyarakat yang konsisten mengawal perjalanan bangsa dan negara hingga saat ini.

Dengan telah diundangkannya UU Ormas tersebut, maka Kemendagri harus siap untuk menerapkan UU Ormas. Hal ini karena kebutuhan masyarakat terhadap keberadaan UU tersebut dinilai cukup tinggi. Tokoh Ormas Nasional Sekjen Pemuda Panca Marga Ishak Tan mengatakan mendukung UU Ormas yang dibuat pemerintah. Alasannya UU ini tak bertentangan dengan UUD 1945. Kalau kita membandingkan UU No. 8/1985 banyak sekali kemajuan yang diakomodir UU Ormas. Misalnya dalam asas ormas. Kalau dulu kan harus sesuai dengan Pancasila dan UUD, tetapi sekarang asalkan tidak bertentangan dengan kedua hal tersebut. Hal itu dinyatakan Ishak dalam perbincangan daerah Bicara KBR68H dan Tempo TV (16/10). Adanya syarat dan ketentuan sampai sanksi diduga menjadi penyebab UU Ormas digugat oleh beberapa ormas. Namun, bagi Ishak, pihaknya tak punya alasan untuk menolak hadirnya UU tersebut. Pemuda Panca Marga juga bakal terus memberikan dukungan dengan mensosialisasikan kepada masyarakat dalam setiap kegiatan yang dilakukan ormasnya. Pandangan tersebut sejalan dengan pandangan bahwa hak setiap ormas di ruang publik perlu di batasi. Hal tersebut pun sudah di atur dalam UUD 1945. Oleh karena itu, adanya ancaman pidana, sanksi ataupun syarat 
dalam UU Ormas tidak perlu ditakutkan oleh setiap ormas. Selama ormas tersebut tak melanggar.

2. Ketentuan-ketentuan pada UU Ormas yang implementasinya perlu pengawasan

Meskipun dalam UU No. 17 Tahun 2013 tentang Organisasi Kemasyarakatan secara eksplisit pengawasan Ormas hanya tertuang pada pasal 53 hingga pasal 56, namun bila diamati lebih mendalam sebenarnya terdapat beberapa pasal yang secara tidak langsung mengandung ketentuan-ketentuan yang membuat keberadaan ormas dan kegiatankegiatannya tidak terlepas dari pengawasan pemerintah maupun masyarakat pada umumnya. Hal ini agar ormas yang ada benar-benar dapat menjalankan perannya secara efektif dalam ikut serta membangun masyarakat sesuai dengan ketentuan peraturan perundang-undangan. Beberapa ketentuan yang dimaksud diantaranya adalah:

Azas ormas tidak bertentangan dengan Pancasila.

Pada Pasal 2 dinyatakan bahwa asas Ormas tidak bertentangan dengan Pancasila dan Undang-Undang Dasar Negara Republik Indonesia Tahun 1945.

\section{Persyaratan Ormas dan Kewajiban Ormas untuk Mendaftarkan Diri.}

Menurut Pasal 12 badan hukum perkumpulan didirikan dengan memenuhi persyaratan: a) akta pendirian yang dikeluarkan oleh notaris yang memuat AD dan ART; b) program kerja; c) sumber pendanaan; d) surat keterangan domisili; e) nomor pokok wajib pajak atas nama perkumpulan; f) surat pernyataan bukan merupakan organisasi sayap partai politik; dan g) surat pernyataan tidak sedang dalam sengketa kepengurusan atau dalam perkara di pengadilan. Pengesahan sebagai badan hukum perkumpulan oleh menteri yang tugas dan tanggung jawabnya di bidang hukum dan hak asasi manusia. Pengesahan sebagai badan hukum perkumpulan dilakukan setelah meminta pertimbangan dari instansi terkait.

Pada Pasal 15 dinyarakan bahwa: (1) Ormas berbadan hukum dinyatakan terdaftar setelah mendapatkan pengesahan badan hukum; (2) Pendaftaran Ormas berbadan hukum dilakukan sesuai dengan ketentuan peraturan perundangundangan; (3) Dalam hal telah memperoleh status badan hukum, Ormas tidak memerlukan surat keterangan terdaftar.

Pada Pasal 16 dinyatakan bahwa: (1) Pendaftaran Ormas yang tidak berbadan hukum dilakukan dengan pemberian surat keterangan terdaftar; (2) Pendaftaran Ormas yang tidak berbadan hukum dilakukan dengan memenuhi persyaratan: a. akta pendirian yang dikeluarkan oleh notaris yang memuat $\mathrm{AD}$ atau AD dan ART; b. program kerja; c. susunan pengurus; d. surat keterangan domisili; e. nomor pokok wajib pajak atas nama Ormas; f. surat pernyataan tidak dalam sengketa kepengurusan atau tidak dalam perkara di pengadilan; dan g. surat pernyataan kesanggupan melaporkan kegiatan; (3) Surat keterangan terdaftar diberikan oleh: a. Menteri bagi Ormas yang memiliki lingkup nasional; $b$. gubernur bagi Ormas yang memiliki lingkup provinsi; atau c. bupati/walikota bagi Ormas yang memiliki lingkup kabupaten/kota.

Pada pasal 17 dinyatakan bahwa: (1) Menteri, gubernur, atau bupati/walikota wajib melakukan verifikasi dokumen pendaftaran paling lama 15 (lima belas) hari kerja terhitung sejak diterimanya dokumen pendaftaran; (2) Dalam hal dokumen permohonan belum lengkap Menteri, gubernur, atau bupati/walikota meminta Ormas pemohon untuk melengkapinya dalam waktu paling lama 15 (lima belas) hari kerja terhitung sejak tanggal penyampaian ketidaklengkapan dokumen permohonan; (3) Dalam hal Ormas lulus verifikasi, Menteri, gubernur, atau bupati/walikota memberikan surat keterangan terdaftar dalam jangka waktu paling lama 7 (tujuh) hari kerja.

Pada Pasal 18 dinyatakan bahwa: (1) Dalam hal Ormas tidak berbadan hukum yang tidak memenuhi persyaratan untuk diberi surat keterangan terdaftar dilakukan pendataan sesuai dengan alamat dan domisili; (2) Pendataan Ormas sebagaimana dimaksud pada ayat (1) dilakukan oleh camat atau sebutan lain; (3) Pendataan Ormas sebagaimana dimaksud pada ayat (1) meliputi: a. nama dan alamat organisasi; b. nama pendiri; c. tujuan dan kegiatan; dan d. susunan pengurus.

Dengan aturan-auran tersebut maka semua bentuk kegiatan berserikat dan berkumpul berada di bawah kontrol Pemerintah, dalam hal ini Kesbangpol Kemendagri. UU ini membawa semua Organisasi baik berbadan hukum (yayasan dan perkumpulan) atau tidak berbadan hukum, dengan semua ragamnya, berada dalam kontrol dan pengawasan pemerintah (Kesbangpol Kemendagri).

\section{Kewajiban Ormas}

Pada Pasal 21 dinyatakan bahwa Ormas berkewajiban: a. melaksanakan kegiatan sesuai dengan tujuan organisasi; b. menjaga persatuan dan kesatuan bangsa serta keutuhan Negara Kesatuan Republik Indonesia; c. memelihara nilai agama, budaya, moral, etika, dan norma kesusilaan serta memberikan manfaat untuk masyarakat; d. menjaga ketertiban umum dan terciptanya kedamaian dalam masyarakat; e. melakukan pengelolaan keuangan secara transparan dan akuntabel; dan f. berpartisipasi dalam pencapaian tujuan negara.

\section{Keuangan ormas}

UU Ormas juga mengatur tentang keuangan ormas dan mewajibkan ormas membuat laporan keuangan ke publik dan sumber pendanaannya dari mana, sebagaimana diatur dalam Pasal 37 dan 38. Pada Pasal 37 dinyatakan bahwa Keuangan Ormas dapat bersumber dari:a.Iuran 
anggota;b.Bantuan/sumbangan masyarakat;c.Hasil usaha Ormas;d.Bantuan/sumbangandari orang asing atau lembaga asing;e.Kegiatan lain yang sah menurut hukum; dan/atauf.Anggaran pendapatan belanja negara dan/atau anggaran pendapatan belanja daerah. Keuangan ormas harus dikelola secara transparan dan akuntabel.Dalam hal melaksanakan pengelolaan keuangannya, Ormas menggunakan rekening bank nasional.

Pasal 38 menyatakan bahwa dalam hal ormas menghimpun dan mengelola dana iuran anggota, Ormas wajib membuat laporan pertanggungjawaban keuangan sesuai dengan standar akuntansi secara umum atau sesuai dengan AD dan/atau ART.Dalam hal ormas menghimpun dan mengelola bantuan/sumbangan masyarakat, ormas wajib mengumumkan laporan keuangan kepada publik secara berkala.Sumber keuangan ormas dilaksanakan sesuai dengan ketentuan peraturan Perundangundangan.

\section{Ormas Asing}

Pada Pasal 44 dinyatakan bahwa Ormas badan hukum yayasan asing atau sebutan lain ajib memiliki izin Pemerintah. Izin Pemerintah dimaksud berupa: a. izin prinsip; dan b. izin operasional. Izin prinsip diberikan oleh menteri yang menyelenggarakan urusan pemerintahan di bidang luar negeri setelah memperoleh pertimbangan tim perizinan. Sedangkan izin operasional diberikan oleh Pemerintah dan Pemerintah Daerah sesuai dengan ketentuan peraturan perundang-undangan. Pada Pasal 45 disebutkan bahwa untuk memperoleh izin prinsip, ormas harus memenuhi persyaratan paling sedikit: a. ormas badan hukum yayasan asing atau sebutan lain dari negara yang memiliki hubungan diplomatik dengan Indonesia; dan b. memiliki asas, tujuan, dan kegiatan organisasi yang bersifat nirlaba. Izin prinsip diberikan untuk jangka waktu paling lama 3 (tiga) tahun dan dapat diperpanjang. Perpanjangan izin prinsip diajukan paling lambat 3 (tiga) bulan sebelum izin prinsip berakhir.

Pada pasal Pasal 46 dinyatakan bahwa izin operasional bagi ormas hanya dapat diberikan setelah ormas mendapatkan izin prinsip. Untuk memperoleh izin operasional, ormas harus memiliki perjanjian tertulis dengan Pemerintah sesuai dengan bidang kegiatannya. Izin operasional diberikan tidak melebihi jangka waktu izin prinsip dan dapat diperpanjang. Perpanjangan izin operasional diajukan paling lambat 3 (tiga) bulan sebelum izin operasional tersebut berakhir.

Pada Pasal 48 diatur bahwa dalam melaksanakan kegiatannya, ormas asing wajib bermitra dengan Pemerintah dan Ormas yang didirikan oleh warga negara Indonesia atas izin Pemerintah. Pada Pasal 49 disebutkan bahwa pembentukan tim perizinan sebagaimana dikoordinasikan oleh menteri yang menyelenggarakan urusan pemerintahan di bidang luar negeri.

Ormas asing juga mempunyai kewajiban dan larangan. Pada Pasal 51 dinyatakan bahwa Ormas yang didirikan oleh warga negara asing berkewajiban: a. menghormati kedaulatan Negara Kesatuan Republik Indonesia; b. tunduk dan patuh pada ketentuan peraturan perundang-undangan; c. menghormati dan menghargai nilai-nilai agama dan adat budaya yang berlaku dalam masyarakat Indonesia; d. memberikan manfaat kepada masyarakat, bangsa, dan negara Indonesia; e. mengumumkan seluruh sumber, jumlah, dan penggunaan dana; dan f. membuat laporan kegiatan berkala kepada Pemerintah atau Pemerintah Daerah dan dipublikasikan kepada masyarakat melalui media massa berbahasa Indonesia.

Sedangkan mengenai larangan, Pasal 52 menyebutkan bahwa Ormas yang didirikan oleh warga negara asing dilarang: a. melakukan kegiatan yang bertentangan dengan ketentuan peraturan perundang-undangan; b. mengganggu kestabilan dan keutuhan Negara Kesatuan Republik Indonesia; c. melakukan kegiatan intelijen; d. melakukan kegiatan politik; e. melakukan kegiatan yang mengganggu hubungan diplomatik; f. melakukan kegiatan yang tidak sesuai dengan tujuan organisasi; g. menggalang dana dari masyarakat Indonesia; dan $h$. menggunakan sarana dan prasarana instansi atau lembaga pemerintahan.

\section{Larangan-larangan terhadap Ormas}

UU No. 17 Tahun 2013 juga mengatur tentang larangan-larangan terhadap Ormas. Pasal 59 menyebutkan bahwa Ormas dilarang untuk: a. menggunakan bendera atau lambang yang sama dengan bendera atau lambang negara Republik Indonesia menjadi bendera atau lambang Ormas; $b$. menggunakan nama, lambang, bendera, atau atribut yang sama dengan nama, lambang, bendera, atau atribut lembaga pemerintahan; c. menggunakan dengan tanpa izin nama, lambang, bendera negara lain atau lembaga/badan internasional menjadi nama, lambang, atau bendera Ormas; d. menggunakan nama, lambang, bendera, atau simbol organisasi yang mempunyai persamaan pada pokoknya atau keseluruhannya dengan nama, lambang, bendera, atau simbol organisasi gerakan separatis atau organisasi terlarang; atau e. menggunakan nama, lambang, bendera, atau tanda gambar yang mempunyai persamaan pada pokoknya atau keseluruhannya dengan nama, lambang, bendera, atau tanda gambar Ormas lain atau partai politik.

Selain itu, Ormas dilarang untuk: a. melakukan tindakan permusuhan terhadap suku, agama, ras, atau golongan; b. melakukan penyalahgunaan, penistaan, atau penodaan terhadap agama yang dianut di Indonesia; c. melakukan kegiatan separatis yang mengancam kedaulatan Negara Kesatuan Republik Indonesia; d. melakukan 
tindakan kekerasan, mengganggu ketenteraman dan ketertiban umum, atau merusak fasilitas umum dan fasilitas sosial; atau e. melakukan kegiatan yang menjadi tugas dan wewenang penegak hukum sesuai dengan ketentuan peraturan perundang-undangan.

Ormas juga dilarang: a. menerima dari atau memberikan kepada pihak mana pun sumbangan dalam bentuk apa pun yang bertentangan dengan ketentuan peraturan perundang-undangan; atau $b$. mengumpulkan dana untuk partai politik. Ormas juga dilarang menganut, mengembangkan, serta menyebarkan ajaran atau paham yang bertentangan dengan Pancasila.

Maraknya Ormas yang bermunculan dan menjadi momok baru premanisme terorganisir di Jakarta.Oleh karena itu aktivis lingkungan Hasnaeni mengatakan bahwa keberadaan ormas masih dibutuhkan dimasyarakat, tapi harus dilakukan pengawasan dan ketegasan dalam pembinaan. Ormas masih dibutuhkan, namun harus dikondisikan, jangan jadi premanisme, bila ada salah satu ormas yang melakukan tindakan premanisme, hal itu karena kurangnya pengawasan dan binaan terhadap ormas tersebut oleh pemerintah daerah. Hal itu dikemukakan oleh Hasnaeni saat dihubungi itoday, Kamis (1/12/2013). Hasnaeni beranggapan bahwa keberadaan ormas-ormas di DKI Jakarta masih perlu pembinaan dan pengawasan, agar keberadaannya menjadi bagian yang bermanfaat dimasyarakat. Menurut Hasnaeni, Pemerintah daerah harus membenahi sistem pengawasan terhadap ormas yang ada dan ketegasan dalam melakukan penindakan untuk menghindari bentuk-bentuk premanisme. Sistem pengawasan yang harus dibenahi dan perlu ketegasan.

Terdapat berbagai bentuk pengawasan terhadap Ormas sebagaimana yang terdapat dalam UU No. 17 Tahun 2013. Secara eksplisit, pada Pasal 53 dinyatakan bahwa: (1) Untuk meningkatkan kinerja dan akuntabilitas Ormas atau ormas yang didirikan oleh warga negara asing sebagaimana dimaksud dalam Pasal 43 ayat (2) dilakukan pengawasan internal dan eksternal; (2) Pengawasan internal terhadap Ormas atau ormas yang didirikan oleh warga negara asing sebagaimana dimaksud pada ayat (1) dilakukan sesuai dengan mekanisme organisasi yang diatur dalam AD/ART; (3) Pengawasan eksternal sebagaimana dimaksud pada ayat (1) dilakukan oleh masyarakat, Pemerintah, dan/atau Pemerintah Daerah. Selanjutnya pada Pasal 54 dinyatakan bahwa: (1) Untuk menjamin terlaksananya fungsi dan tujuan Ormas, setiap Ormas atau ormas yang didirikan oleh warga negara asing sebagaimana dimaksud dalam Pasal 43 ayat (2) memiliki pengawas internal; (2) Pengawas internal sebagaimana dimaksud pada ayat (1) berfungsi untuk menegakkan kode etik organisasi dan memutuskan pemberian sanksi dalam internal organisasi; (3) Tugas dan kewenangan pengawas internal sebagaimana dimaksud pada ayat (1) diatur dalam
AD dan ART atau peraturan organisasi. Bentukbentuk pengawasan diatur dalam Pasal 55 yang menyatakan bahwa: (1) Bentuk pengawasan oleh masyarakat sebagaimana dimaksud dalam Pasal 53 ayat (3) dapat berupa pengaduan; (2) Pengaduan sebagaimana dimaksud pada ayat (1) disampaikan kepada Pemerintah atau Pemerintah Daerah. Sedangkan pada Pasal 56 dinyatakan bahwa Ketentuan lebih lanjut mengenai pengawasan oleh masyarakat, Pemerintah dan/atau Pemerintah Daerah terhadap Ormas atau ormas yang didirikan oleh warga negara asing sebagaimana dimaksud dalam Pasal 53 sampai dengan Pasal 55 diatur dalam Peraturan Pemerintah.Sementara pada Pasal 58 disebutkan pula bahwa bentuk pengawasan Pemerintah dan/atau Pemerintah Daerah sebagaimana dimaksud dalam Pasal 54 ayat (3) berupa pemantauan dan evaluasi.

Salah satu bagian penting dari pengawasan Ormas adalah menyangkut proses pembekuan ormasormas yang dianggap radikal. Pengawasan dan penindakan terhadap ormas radikal sebelum diundangkannya UU No. 17 Tahun 2013 didasarkan pada UU No. 8 Tahun 1985 dan Peraturan Pemerintah No. 18 Tahun 1985. Akan tapi, pengalaman menunjukkan bahwa peraturan tersebut dirasakan kurang pas karena terlalu lambat dan berbelit. Berdasarkan aturan tersebut ormas yang melakukan pelanggaran harus ditegur dulu sebanyak dua kali. Jika masih melanggar akan dibekukan. Jika tetap melanggar, baru dibubarkan.Pembubaran ormas pun harus melalui fatwa Mahkamah Agung. Jika pembubaran diusulkan pemerintah daerah, harus dengan persetujuan menteri dalam negeri. Proses ini kemudian menjadi persoalan,jika ormas sekarang melakukan kesalahan, lalu besok tidak melakukan lagi, menjadi sulit untuk diambil tindakan. Hal ini yang menyebabkan masyarakat merasa pemerintah tidak berbuat apa-apa dengan adanya ormas-ormas radikal yang ada saat ini. Sebabnya, peraturan hukum untuk penindakan ormas itu memang lambat dan terlalu panjang. Padahal peraturan hukum itulah yang menjadi pegangan pemerintah. Dengan adanya UU No. 17 Tahun 2013 maka memperpendek proses tersebut dipersingkat. UU Ormas juga mengatur ormas-ormas yang tidak terdaftar, karena pada UU sebelumnya tidak mengatur tindakan terhadap ormas yang tidak terdaftar, sehingga jika ada ormas semacam ini bertindak radikal, pemerintah tak bisa berbuat apa-apa.

\section{Hal-hal yang perlu diatur dalam Rancangan Peraturan Pemerintah Tentang Pengawasan Ormas}

Berdasarkan deskripsi dan pembahasan sebagaimana dikemukakan di atas, maka dalam rangka mengimplementasikan pasal 53 hingga pasal 56 UU No. 17 Tahun 2013 tentang Organisasi Kemasyarakatan, maka rancangan peraturan 
pemerintah tentang pengawasan Ormas perlu mengatur berbagai hal.

Pertama, konsideran, yakni bagian menimbang dan mengingat. Bagian menimbang berisi pertimbangan diperlukannya peraturan pemerintah tentang pengawasan Ormas, sedangkan bagian mengingat berisi ketentuan perundangundangan yang menjadi acuan dalam penyusunan peraturan pemerintah tentang pengawasan Ormas.

Kedua,ketentuan umum, yang memuat tentang pengertian atau definisi umum mengenai istilah yang digunakan dalam Rancangan Peraturan Pemerintah. Rumusan pengertian atau definisi istilah yang digunakan mengacu pada rumusan pengertian yang digunakan oleh UU No. 17 Tahun 2013 tentang Organisasi Kemasyarakatan. Beberapa definisi yang diperlukan diantaranya adalah definisi tentang organisasi kemasyarakatan, pengawasan, pengawasan internal, dan pengawasan eksternal.

Ketiga,substansi pengawasan Ormas oleh pemerintah. Bagian ini berisi aturan yang rinci mengenai tujuan, bentuk-bentuk, tata cara pengawasan, maupun bentuk-bentuk sanksi yang bisa diberikan oleh pemerintah terhadap Ormas. Pada bagian ini perlu diatur: a) tujuan pengawasan Ormas, yakni untuk menjamin terlaksananya fungsi dan tujuan Ormas; b) pengawasan internal dan pengawasan eksternal, yakni bahwa setiap Ormas harus memiliki lembaga pengawas internal maupun eksternal.

Lembaga pengawas internal berfungsi untuk menegakkan kode etik organisasi dan memutuskan pemberian sanksi dalam internal Ormas. Tugas dan kewenangan lembaga pengawas tersebut diatur dalam AD dan ART atau peraturan organisasi. Selanjutnya, dalam rangka pengawasan eksternal, untuk meningkatkan akuntabilitas organisasi, Ormas wajib membuat laporan kegiatan dan keuangan yang terbuka untuk publik. Untuk itu perlu diatur pedoman maupun tata cara pembuatan laporannya.

Dalam hal pengawasan terhadap Ormas, masyarakat berhak menyampaikan dukungan atau keberatan terhadap keberadaan atau aktivitas Ormas. Dukungan antara lain dapat berupa pemberian penghargaan, program, bantuan dana, dan dukungan operasional organisasi. Sedangkan, keberatan diajukan masyarakat kepada Pemerintah atau Pemerintah Daerah sesuai tingkatan. Dalam hal terdapat pengajuan keberatan tersebut, maka Pemerintah atau Pemerintah Daerah mengupayakan penyelesaian keberatan melalui mekanisme mediasi dan konsiliasi.Bentuk-bentuk serta tata cara dukungan maupun keberatan dari masyarakat tersebut perlu diatur lebih lanjut secara lebih detil.

Keempat, penutup. Bagian ini mengatur tentang waktu pemberlakuan peraturan pemerintah dan tentangpemberlakuan peraturan pemerintah sejak tanggal diundangkan, serta agarsetiap orang UU No. 17 Tahun 2013 tentang Organisasi Kemasyarakatan mengetahui maka peraturan pemerintah dapat ditempatkan di dalam Lembaran Negara Republik Indonesia.

\section{KESIMPULAN}

Bahwa di satu sisi keberadaan ormas memberikan kontribusi yang tidak kecil dalam pembangunan, namun di sisi lain masih banyaknya organisasi masyarakat yang bertindak anarkis dan menganggu dalam lingkungan masyarakat, akibatnya masyarakat menjadi merasa terancam dan tidak aman. Implementasi UU Ormas secara efektif di lapangan tidak dapat ditunda lagi. Untuk itu seluruh ketentuan operasional dalam rangka implementasi UU Ormas harus sudah tersedia.Hal-hal substansial yang perlu diatur dalam pengawasan ormas adalah aturan-aturan yang rinci mengenai tujuan, bentukbentuk, tata cara pengawasan, maupun bentukbentuk sanksi yang bisa diberikan oleh pemerintah terhadap Ormas.

Pemerintah perlu memberikan tindakan tegas kepada organisasi masyarakat (ormas) yang melakukan tindakan anarkis dan menganggu keamanan dan ketertiban umum. Salah satu aturan operasional yang diperlukan adalah peraturan pemerintah tentang pengawasan ormas. Adapun Substansi peraturan pemerintah tentang pengawasan ormas perlu mengatur berbagai aspek pengawasan ormas secara lebih operasional sebagaimana telah diatur dalam pasal 53 hingga 56 UU Ormas.Hal-hal yang perlu di atur dalam pengawasan ormas adalah : a) tujuan pengawasan Ormas, yakni untuk menjamin terlaksananya fungsi dan tujuan Ormas; b) pengawasan internal dan pengawasan eksternal, yakni bahwa setiap Ormas harus memiliki lembaga pengawas internal maupun eksternal.

\section{Daftar Pustaka}

Adi Suryadi Culla, 2006, Rekontruksi Civil Society Wacana dan Aksi Ornop di Indonesia, Jakarta: Pustaka LP3ES.

Badan Legislasi DPR RI, 2013, Naskah Akademik Undang-undang Organisasi Kemasyarakatan. Kalyanamitra, Catatan Media, Juli 2013.

Lembaga Studi dan Advokasi Masyarakat (ELSAM), 2013, Catatan Kelemahan Pasal-pasal Dalam RUU Ormas.

Siagian, Sondang P. 1995. Teori Pengembangan Organisasi. Jakarta: Bumi Aksara.

Jeirry Sumampow, Peran Ormas dan Pentingnya Revisi UU No. 8 Tahun 1945 tentang Ormas, Civis Vol. 3 No. 1 Jul 2011.

Jimly Assdidiqie, Mengatur Kebebasan Berserikat Dalam Undang-Undang, http://www.jimlyschool.com/read/analisis/274/ mengatur-kebebasan-berserikat-dalam undangundang

http://faizmiftah.blogspot.com/2011/11/tugasormas.html 
http://id.wikipedia.org/wiki/Lembaga_Swadaya_Masya rakat

http://news.detik.com/read/2010/12/10/055843/1514950

/10/pengawasan-pemprov-dki-terhadap-ormas-dinilailemah?nd992203605

http://syahminan.blogspot.com/2013/06/pengawasan-

terhadap-ormas-dal-lsm-di.html

http://www.bidikkasus.com/uu-no-17-tahun-2013-

ormas-anarkis-dibekukan/

http://www.hukumonline.com/berita/baca/lt5321da4723

79e/uu-ormas-mulai-memakan-korban

http://www.jpnn.com/read/2013/10/25/197447/Ormas-

Harus-Punya-Mekanisme-Pengawasan-Internal-

http://www.kesbangpolbulukumba.info/berita-

sambutan--dirjen-kesbangpol------pada-----pertemuan-sosialisasi-undangundang--nomor-17-tahun-2013-.html http://mediabanten.com/content/kesbangpol-perketat-

pengawasan-ormas

http://www.merdeka.com/jakarta/fbr-pemuda-pancasilasaling-serang-di-kemayoran.html

http://www.merdeka.com/peristiwa/bawa-golok-fbr-

dan-pemuda-pancasila-bentrok-di-johar-baru.html http://www.merdeka.com/peristiwa/dua-ormas-didepok-bentrok-satu-orang-kena-bacok.html http://www.merdeka.com/peristiwa/polisi-sita-banyaksenjata-tajam-dari-12-anggota-pp-yang-ditahan.html http://www.merdeka.com/peristiwa/bentrok-ormas-dan-

lsm-di-karawang-2-mobil-dibakar-massa.html http://www.merdeka.com/peristiwa/rebutan-lahanparkir-2-ormas-di-denpasar-terlibat-bentrok.html http://www.merdeka.com/peristiwa/diserbu-2kelompok-ormas-sidang-pembunuhan-di-gianyarditunda.html

http://www.merdeka.com/peristiwa/dua-ormas-bentrokdi-medan-2-orang-luka-14-diamankan.html http://www.portalkbr.com/berita/perbincangan/2981665 4215.html

http://www.solopos.com/2012/07/06/pemerintah perketat-pengawasan-ormas-308985

http://www.suarapembaruan.com/home/pemerintahsiapkan-enam-pp-lengkapi-uu-ormas/38883 http://www.republika.co.id/berita/nasional/umum/13/03 /12/mjjl1w-pemerintah-harus-awasi-gerakan-setiapormas 
20 | Jurnal Bina Praja | Volume 7 Nomor 1 Edisi Maret 2015 : 1 - 20 